\title{
Web 2.0 Technology Adoption by Government Departments
}

\author{
by \\ Iveta Markova \\ A thesis submitted to the Faculty of Graduate Studies and Research in partial fulfilment \\ of the requirements for the degree of Master of Applied Science in \\ Technology Innovation Management \\ Department of Systems and Computer Engineering \\ Carleton University \\ Ottawa, Canada K1S 5B6
}

September 2008

C Copyright 2008 Iveta Markova 


$\begin{array}{ll}\begin{array}{l}\text { Library and } \\ \text { Archives Canada }\end{array} & \begin{array}{l}\text { Bibliothèque et } \\ \text { Archives Canada }\end{array} \\ \begin{array}{l}\text { Published Heritage } \\ \text { Branch }\end{array} & \begin{array}{l}\text { Direction du } \\ \text { Patrimoine de l'édition }\end{array} \\ \begin{array}{l}\text { 395 Wellington Street } \\ \text { Ottawa ON K1A 0N4 } \\ \text { Canada }\end{array} & \begin{array}{l}\text { 395, rue Wellington } \\ \text { Ottawa ON K1A 0N4 } \\ \text { Canada }\end{array}\end{array}$

Your file Votre référence ISBN: 978-0-494-47517-1 Our file Notre référence ISBN: 978-0-494-47517-1

NOTICE:

The author has granted a nonexclusive license allowing Library and Archives Canada to reproduce, publish, archive, preserve, conserve, communicate to the public by telecommunication or on the Internet, loan, distribute and sell theses worldwide, for commercial or noncommercial purposes, in microform, paper, electronic and/or any other formats.

The author retains copyright ownership and moral rights in this thesis. Neither the thesis nor substantial extracts from it may be printed or otherwise reproduced without the author's permission.
AVIS:

L'auteur a accordé une licence non exclusive permettant à la Bibliothèque et Archives Canada de reproduire, publier, archiver, sauvegarder, conserver, transmettre au public par télécommunication ou par l'Internet, prêter, distribuer et vendre des thèses partout dans le monde, à des fins commerciales ou autres, sur support microforme, papier, électronique et/ou autres formats.

L'auteur conserve la propriété du droit d'auteur et des droits moraux qui protège cette thèse. $\mathrm{Ni}$ la thèse ni des extraits substantiels de celle-ci ne doivent être imprimés ou autrement reproduits sans son autorisation.
In compliance with the Canadian Privacy Act some supporting forms may have been removed from this thesis.

While these forms may be included in the document page count, their removal does not represent any loss of content from the thesis.
Conformément à la loi canadienne sur la protection de la vie privée, quelques formulaires secondaires ont été enlevés de cette thèse.

Bien que ces formulaires aient inclus dans la pagination, il n'y aura aucun contenu manquant.

\section{Canada}


The undersigned hereby recommend to the Faculty of Graduate Studies and Research acceptance of the thesis

\title{
Web 2.0 Technology Adoption by Government Departments
}

\author{
Submitted by \\ Iveta Markova
}

In partial fulfillment of the requirements for the degree of Master of Applied Science in Technology Innovation Management

Victor C. Aitken, Department Chair

Douglas King, Thesis Supervisor

\author{
Department of Systems and Computer Engineering \\ Carleton University Ottawa, Canada, K1S 5B6
}

September 2008 


\begin{abstract}
This exploratory research examines the degree of adoption of Web 2.0 technologies in eight Canadian Federal Government Departments and identifies the factors that affect the adoption. Data from interviews conducted in the Government Departments is analyzed and used to identity; (i) factors that drive adoption of Web 2.0 technologies, (ii) factors that make adoption challenging, and (iii) the best practices for adoption of new technologies in the government. Nine propositions are offered. Analysis of the results suggest that; (i) individual motivational behaviour affects usage of new collaboration tools, and (ii) organizational response to changes caused by Web 2.0 technologies affects their adoption. Finally, an analysis of this research provides a list of best proven practices for adoption of new technologies in the government.
\end{abstract}




\section{ACKNOWLEDGEMENTS}

I would like to express my gratitude to my supervisor Professor Douglas King for his dedication, stimulating suggestions, and guidance throughout this study.

I would like to thank Professor Toni Bailetti for his constructive suggestions, support and ideas for improvement of this study throughout the program.

I am also thankful to Professor Stoyan Tanev, Professor Michael Weiss and Professor Steven Muegge for their suggestions during my gate presentations.

I thank my family for their continuous support and endless love.

Finally, I would like to thank all my friends for being such a wonderful source of encouragement and support. 


\section{TABLE OF CONTENTS}

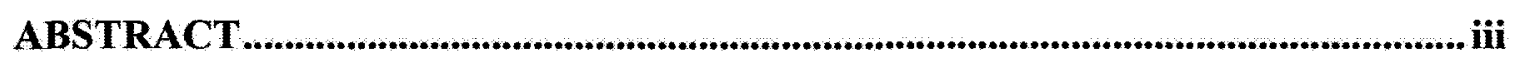

TABLE OF CONTENTS ...................................................................................................... v

LIST OF FIGURES ............................................................................................... vii

LIST OF TABLES ...................................................................................................................... vii

1. INTRODUCTION....................................................................................................................... 1

1.1 Goals and Objectives .................................................................................................... 2

1.2 Deliverables .................................................................................................................................. 4

1.3 Relevance …................................................................................................................................ 4

1.4 Contribution ................................................................................................................. 6

1.5 Research Model......................................................................................................................... 7

1.6 Organization ............................................................................................................................ 8

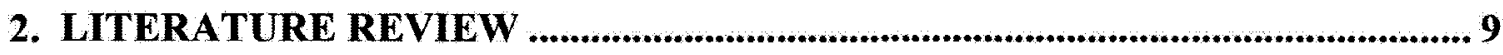

2.1 Web 2.0 Technology ......................................................................................................9

2.2 Adoption of Web 2.0 in the Government .................................................................. 11

2.3 Employees' Engagement to Use Web 2.0 Technologies......................................... 15

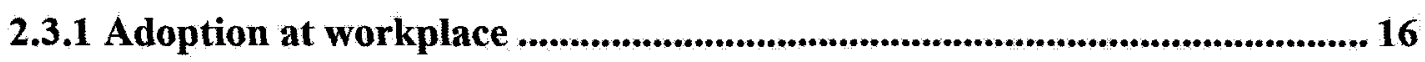

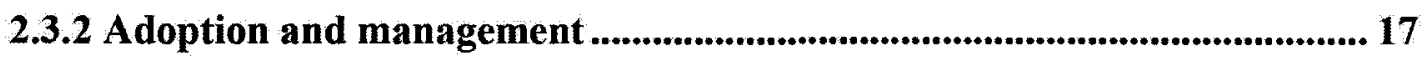

2.3.3 Adoption process .............................................................................................................. 18

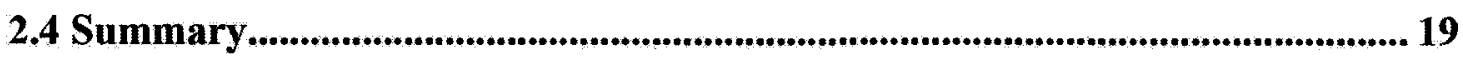

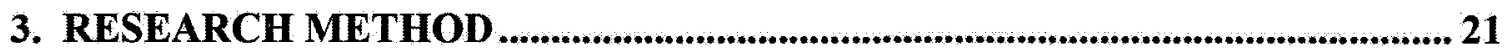




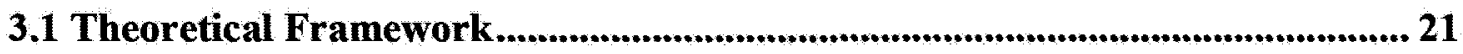

3.2 Unit of Analysis, Study Period and Sample Selection ................................. 23

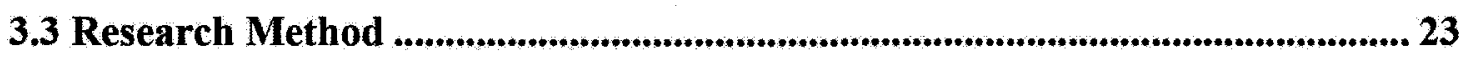

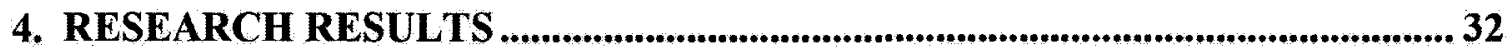

4.1 PHASE I - Preliminary Research ............................................................ 32

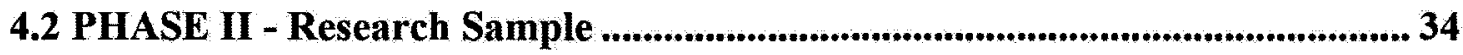

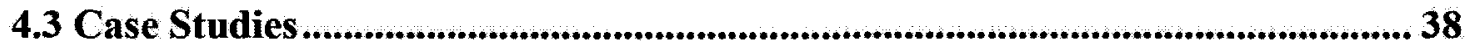

4.4 Factors Having a Positive Impact on Adoption of Web 2.0 ..........................48

4.5 Factors Having a Negative Impact on Adoption of Web 2.0......................... 51

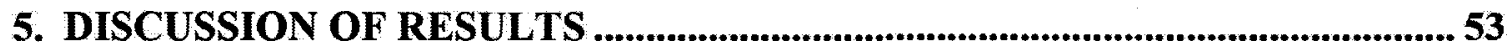

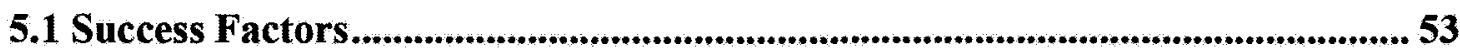

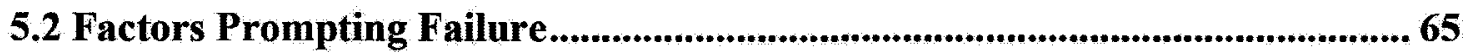

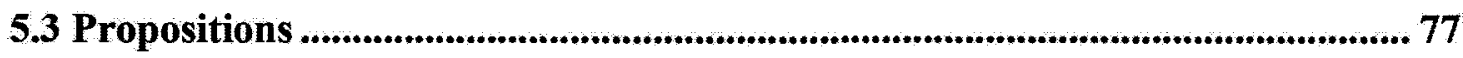

6. CONCLUSIONS, LIMITATIONS AND SUGGESTIONS FOR FUTURE

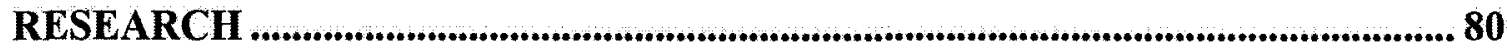

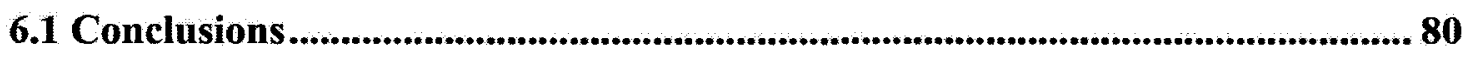

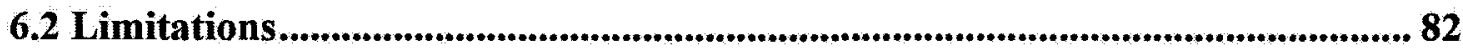

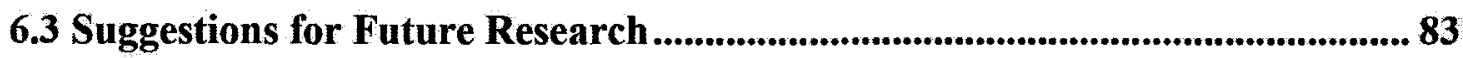

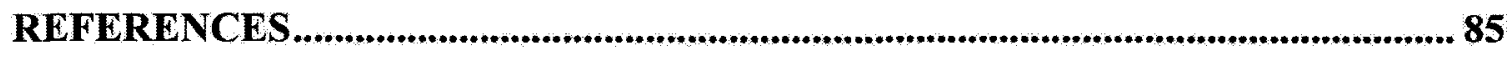

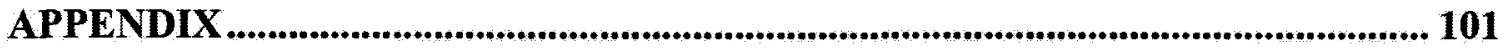




\section{LIST OF FIGURES}

Figure 1: Research model................................................................................................ 8

Figure 2: A proposed public sector service value chain (adapted form the source:

Heintzman and Marson, 2003)............................................................................... 13

Figure 3: The adoption process (taken form the source: Spence, 1994).................. 18

Figure 4: Model representing motivational factors that affect adoption of Web 2.0

\section{LIST OF TABLES}

Table 1: Key highlights from the literature review ............................................. 19

Table 2: Research sample of web applications used by Canadian governments ..... 36

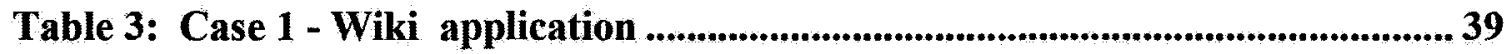

Table 4: Case 2 - Wiki web site......................................................................... 40

Table 5: Case 3 - Wiki web site................................................................................ 41

Table 6: Case 4 - Java application with blogs ........................................................ 43

Table 7: Case 5 - Blogging application ................................................................ 44

Table 8: Case 6 - Project application using wikis.................................................... 45

Table 9: Case 7 - Blogging application .......................................................................... 46

Table 10: Case 8 - Blogging application................................................................... 47

Table 11: Main drivers to use collaboration tools and participate in collaboration 49

Table 12: Top barriers to further success of Web 2.0 initiatives...............................52

Table 13: Five of the most important success factors........................................... 54 
Table 14: Five of the most important failure factors......................................................66

Table 15: Suggested best practices ................................................................................ 76

Table 16: E-government adoption and acceptance: organizational benefits

(adapted from: Titah and Barki, 2005).......................................................................... 101

Table 17: E-government adoption and acceptance: knowledge sharing (adapted

from: Titah and Barki, 2005)............................................................................................ 102

Table 18: E-government adoption and acceptance: knowledge creation (adapted

from: Titah and Barki, 2005).................................................................................................... 103

Table 19: E-government adoption and acceptance: enhanced employee

participation (adapted from: Titah and Barki, 2005) ..................................................... 104

Table 20: E-government adoption and acceptance: make work easier (adapted

from: Titah and Barki, 2005).................................................................................................... 105 


\section{INTRODUCTION}

New emerging Internet-based collaboration technologies, referred to as Web 2.0, have changed the way people use the Internet. During the past years, non-governmental organization services have been significantly affected by consumer behaviours and experiences offered by using these tools. By recognizing the importance of the Web 2.0 technologies, different levels of governments in Canada have begun using these tools in their interaction with citizens. Although implementation of Web 2.0 technologies offers government great opportunities to improve citizen participation, it also poses new challenges with several issues.

This research began with an expectation of finding similarities with other studies around the process of e-Government adoption, for example those studying the introduction of Internet technologies as a platform for exchanging information and delivering public services. In our preliminary study in Phase 1 to identify Web 2.0 adopters, we found very few adopters of new collaboration tools. We identified only eight web applications as early adopters of Web 2.0 technologies. In Phase 2 , we continued the study to identify the dominant factors in adoption. We originally expected, from evidence during Phase 1 , that security and privacy issues would be dominant factors in adoption, but the data did not turn out to support that assumption. 
Because we were researching an area involving unknown phenomena and early adoption stages, the research used an exploratory method. In the research, we assumed that technologies were adopted if they were integrated into a current working process while making that process easier. Under Web 2.0 technologies we included all Internet-based collaboration tools and social software found to be used in the Government. At the time of our investigation, there was a lack of usage of collaboration tools other than wikis and blogs, so our focus stayed only on these two tools.

\subsection{Goals and Objectives}

\section{Goals}

The main goal of this research is to study the use of Web 2.0 technologies within the Government of Canada in the following ways:

1. Applicability in the Internet and intranet government applications

2. Usability in the current applications

3. Identifying issues connected with adoption

\section{Objectives}

Despite several successes with adoption Web 2.0 technologies, most government organizations are behind their implementation goals. The objective of this research is to examine why the implementation of new Internet technologies is not happening faster, 
what are the possible problems or excuses, and how to prevent these problems. This research answers three questions:

1. What are the factors that drive adoption of Web 2.0 technologies?

2. What are the issues that make adoption challenging?

3. What are the best practices for adoption of new technologies in the government?

This research uses the conceptual framework of key factors and best practices from a literature review based on implementation of Information and Communication Technologies (ICT) in Government (Gichoya, 2005). The key factors are identified and categorized under the common categories for success (Moran, 1998, Riley 2000, Khaled, 2003) and failure (Khaled, 2003; Gakunu, 2004; Ndou, 2004). Best practices are proposed to increase the impact of factors for success and reduce the impact of factors for failure (Clockwork, 2004; Ilfinedo, 2005; Gichoya, 2005). 


\subsection{Deliverables}

The outcomes of this research were:

1. An action plan for IT government departments to balance continuity of services while implementing innovative technologies

2. A list of factors that affect adoption of new web technologies within the Government of Canada

3. Propositions describing relationship between different factors and successful implementation of new web technologies

\subsection{Relevance}

This research is relevant to at least four groups of people. First, senior Federal Public Service Managers can use the results of this research to speed the successful adoption of new technologies to allow rapid availability of information to the public. The new Web 2.0 models, built with wikis and blogs, emphasize simplicity, usability and participation. Implementing these collaboration models into their policies, top government management will have a chance to prove their management policy philosophy which is based on transparency, honesty, trust and reputation (Richard, 2006). 
Second, project managers are always interested in more efficient project management tools and practices that would reduce development time, increase project quality and decrease project cost. Using collaboration technology, such as blogs and wikis, would equip project managers with additional collaboration tools and, at the same time, it will empower the project staff with a new way of communication and collaboration (GTEC, 2007).

Third, the public will be interested in building government policies through collaboration with government offices and using forums on the government web sites as a type of feedback representing public opinion. The presence of public opinion would help to manage the content of policy drafts (O'Reilly, 2005).

Last, entrepreneurs will benefit indirectly because they can use business intelligence techniques to define business solutions which are more closely aligned with target markets. With government help, corporations can explore a collaborative approach to their business development. From a public opinion perspective, entrepreneurs can predict changes in markets and focus their businesses according to the perceived changes (Espiner, 2006). 


\subsection{Contribution}

The subject of e-Government and the adoption of collaborative technologies are relatively new subjects in the academic world. Most researchers have contributed with the study of adoption e-government and innovation in government. This research fills a gap based on the fact that the research on the factors that motivate adoption Web 2.0 is lacking.

This research provides at least three contributions to the existing body of knowledge. First, the research identifies the factors that help government departments successfully adopt Web 2.0 technologies within its organization. Considering Web 2.0 tools as innovative technologies, this research will contribute to the e-Government adoption literature and as well, to the literature about adopting innovations.

Second, this research builds on the ICT implementation literature to identify motives for departments who intend to use Web 2.0 in the near future.

The third contribution this research makes is that it provides concrete examples of how government departments use new web technologies to create changes in their collaborative environments. 


\subsection{Research Model}

To adopt new technologies in government, first, government employees must have the

desire to use these technologies, and second, managers must be motivated and committed to adopt them.

Figure 1 represents a research model based on the Public Sector Value Chain (Heintzman and Marson, 2003). The model illustrates links between public trust and confidence in government and client services, and links between these services and employment satisfaction. The shaded areas of the chart represent our focus on the factors that affect intention to use new technologies in government departments. Under motivational factors we include what motivated government employees and how they were motivated to used new collaboration technologies. Organizational factors are events, processes and policies they contribute to relationship between organization and employees.

Motivational and organizational factors are independent variables that can be examined and shown to be an important predictor of employees' satisfaction to use Web 2.0 technologies. The arrow connecting motivational and organizational factors with the employee intention to use Web 2.0 represents a casual relationship between theses two blocks. 


\section{Figure 1: Research model}

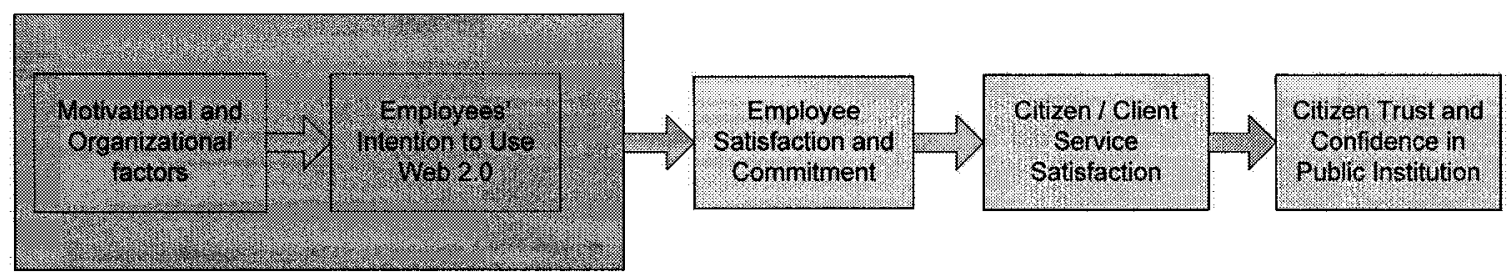

\subsection{Organization}

This thesis is organized into six chapters. Chapter 1 provides the introduction. Chapter 2 reviews the relevant literature. Chapter 3 presents the method used to undertake this research. Chapter 4 provides the results of the research. Chapter 5 discusses the results. Finally, Chapter 6 provides the conclusions of the study, identifies limitations of the research and suggests opportunities for future research.

The Appendix contains a number of figures and tables that were an important outcome of the literature review, and have been included for the convenience of the reader. 


\section{LITERATURE REVIEW}

This chapter is organized into four sections. The first section explains the purpose of Web 2.0 tools. The second section describes how adoption of these tools by the Canadian Government can foster interaction by Canadian citizens. The third section reviews different incentives for government employees to use new Web 2.0 technologies. The last section summarizes our findings from the literature review.

\subsection{Web 2.0 Technology}

\section{Introduction}

Private organizations and a growing number of government departments are recognizing the great opportunities Web 2.0 technologies offer. Despite several successes, government departments are hesitant to adopt these tools in their applications (Gartner, 2007). There are several reasons for this but almost none of them seem to be technology related. It is believed that the group of Web 2.0 tools such as wikis and blogs may bring a variety of potential benefits and serious challenges. To take advantage of new web technology tools, government managers must understand all uncertain factors and overcome some issues with regard to implementation. 


\section{Definitions}

According to O'Reilly, 2005, Web 2.0 is a set of economic, social and technology trends based on open user participation and networking.

Blogs are web-based entries of information written regularly by one person or a group. This on line journal enables people to engage in knowledge sharing and debates.

$A J A X$ stands for Asynchronous JavaScript and $\mathrm{XML}$, which is able to update sections of a web page without refreshing the whole page.

A mash-up is a composite application based on other components or services put together.

$A W i k i$ is a collaborative tool, in which authors create individual web pages that can be created and edited by anybody with access to it. By using the openness functionality, a user community can author pages as a group. Wiki pages are easy to create without any technical knowledge. They use a simple text-based language for content. A good example of wiki usage may be found in the well-known web site -Wikipedia. 


\subsection{Adoption of Web 2.0 in the Government}

The Internet has affected the life of many citizens by changing the old model of static pages into a wide range of networked social services based on Web 2.0 technologies. In his research, Chadwick (2008) analyzes incentive structures that shape how citizens and public servants behave on-line and recognizes values of new e-democracy programs for public policy making and consultation. He suggests the Internet be used as a platform for political disclosure while recognizing two important factors: the power of easy scalable networks and the power of the "long tail" (Anderson, 2006) in a more diverse and pluralistic media landscape.

\section{Citizen trust and confidence in potential use of Web 2.0 by the Government of}

\section{Canada}

Substantial research has been conducted in recent years with a view to determining how to improve citizen's trust and confidence in government, their related motivators and their connection to public participation and engagement in government (AAFC, 2008). According to EKOS Research (2002), there is evidence about declining civic engagement and democratic participation in the government, which is consistent with declining public confidence in our public sector institutions.

Innovations associated with Web 2.0 technologies, and their use in government applications, provide the government with an opportunity to interact with citizens and 
engage them in the democratic process. To explore Canadians' perceptions on using these new technologies, Agriculture and Agri-Food Canada (AAFC) recently undertook research with the public to determine if the use of these new technologies would be useful for the public in their communication efforts with government (AAFC, 2008). The research concluded decisively that the public believes the government should use these new technologies to communicate with and provide services to citizens.

A number of studies in the private sector identified relationships between employee satisfaction and customer satisfaction; customer loyalty, profit, and growth; and employee capability, loyalty, satisfaction and productivity (Heskett et al, 1997; Oakley, 2005). Heintzman and Marson (2003), who based their work upon research conducted in the private sector, created the public sector service value chain model, an updated version of which has been illustrated in Figure 2. This model focuses on the role of public service delivery in enhancing citizen trust and confidence. Their work reviews some drivers and provides evidence for links in the chain between employee engagement (satisfaction and commitment) and client satisfaction in the public sector, as well as between public sector client satisfaction and citizen trust and confidence. 
Figure 2: A proposed public sector service value chain (adapted form the source: Heintzman and Marson, 2003)

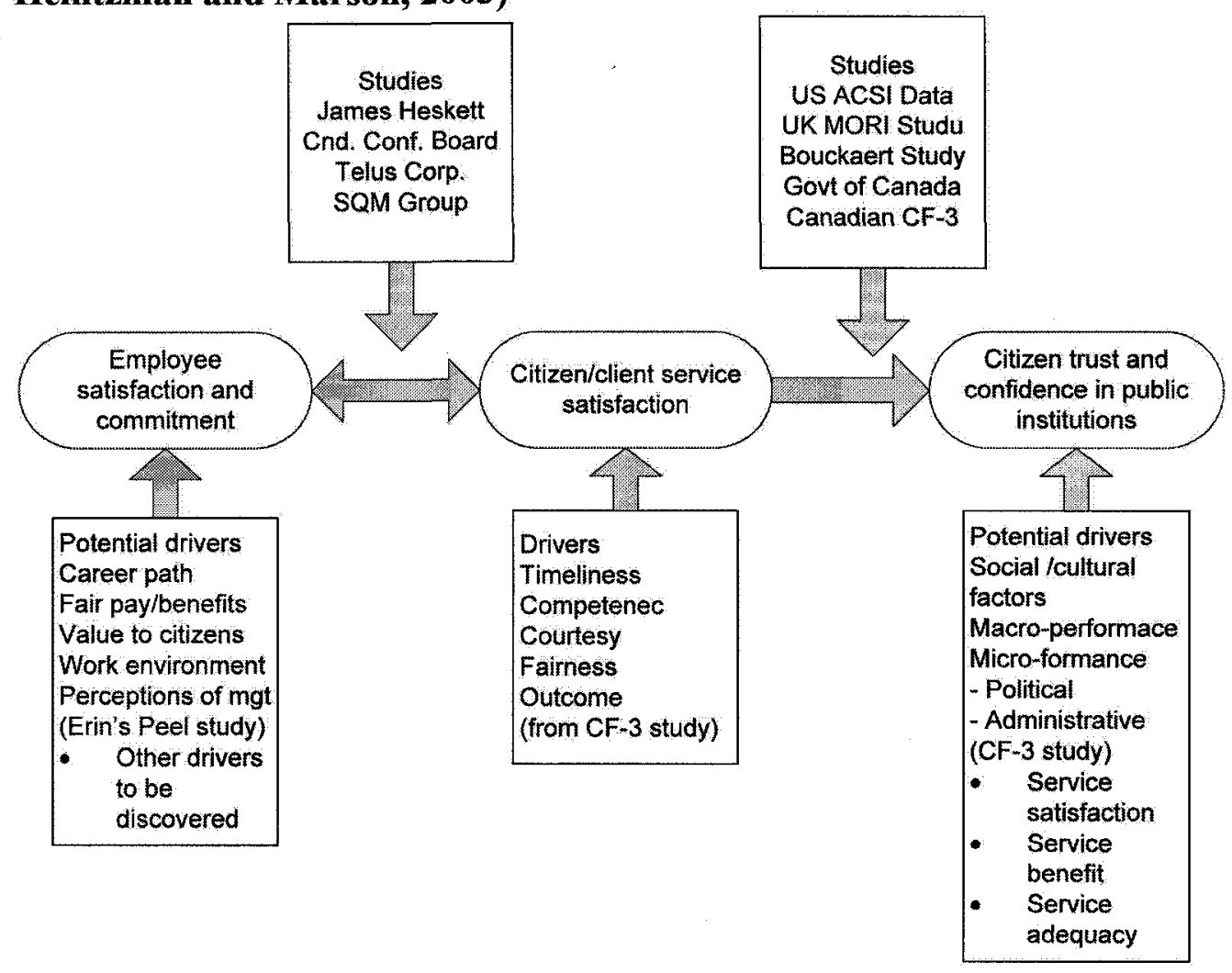

\section{Citizen / customer service satisfaction}

Researchers have tried to interpret the relationship between the commitment of public servants and the satisfaction of citizens with the quality of government service. A study conducted within the Canadian government suggests that there is a strong reciprocal relationship between employee and citizen satisfaction (Van de Walle, 2004; Hentzman and Marson, 2003). Research has shown through many examples that there is a positive 
correlation between the complexity of government employee services and employee satisfaction, which has a great impact on achieving customer satisfaction (Michiak and Desmarais, 2000; Desmarais and Kennedy, 2003; SQM, 2005).

The fact that satisfaction with government leads to greater citizen trust (Fornell, 2002), results in a relationship among service quality, trust and confidence. This can be used to identify different factors influencing trust across public organizations (MORI, 2003). Citizens First National Survey, in 1998, identified five major factors that drive public sector satisfaction: timeliness, knowledge and competence of staff, courtesy/comfort, fair treatment and outcome (Citizens First, 1998).

\section{Employee satisfaction and commitment}

The literature review has revealed various approaches that have identified relationships, drivers and factors about employee satisfaction and commitment in the government. Schmidt (2004) observed that satisfaction is based on an attitude or feeling, while commitment is an expression of patterns of behaviour while shifting to engagement (Hewitt, 2003).

The most significant research, based on employee surveys, identified the following drivers with the largest impact on satisfaction in the public sector: authority in the job, adequate training, feeling appreciated, clarity of departmental goals, and recognition for good work (Vieira, 2002). The public sector study, conducted by Erin Research for the 
Region of Peel in Ontario, found that job satisfaction is a driver of commitment, but commitment is not a driver of satisfaction.

\subsection{Employees' Engagement to Use Web 2.0 Technologies}

There is growing pressure from the public to adopt Web 2.0 technologies by government. There exists a public perception that adoption would help facilitate two-way communication between citizens and the Government. According to a Forrester Report from 2008, most IT managers and CIOs in large companies will make it a priority this year to invest in Web 2.0 technology and embrace social networks in their business. According to a Gartner Report, e-government transformation strategies did not deliver the intended results. There is belief that government business models based on Web 2.0 mashable services and content can overcome some of the existing government issues (Gartner, 2007).

The Canadian Government is recognizing and learning how government leaders worldwide are using innovation in web technologies to deal with better access to service (Egger and Goldsmith, 2004).

At the GTEC 2007 Canadian Government Conference, federal, provincial, municipal, and regional leaders shared that they were exploring a new era of Government 2.0 collaboration. The purpose of the conference was to address the emergence of Web 2.0 technologies and share knowledge and professional experience in serving citizens using Web 2.0 technologies. 


\subsubsection{Adoption at workplace}

Rogers (1995) analyzed user adoption of new technologies in his theory on diffusion of innovation. He named five factors affecting the rate of diffusion, namely relative advantage, complexity, compatibility, trialability and observability. Other researchers concluded that relative advantage, compatibility and complexity are the most relevant factors to adoption (Carter and Belanger, 2005). Compatibility, trust and image factors were linked to the intention to use new technologies (Karahanna et al. 1999; Moon \& Bretschneider, 2002).

Some organizational factors, such as management capacity to direct, personal and professional training, human resource management, understanding the technology, external political influence, external pressures, clear guidelines, and open cultures will affect organizational behaviour. These factors will all have an impact on successful adoption of Web 2.0 (Scatolini and Cordela, 2005; Ventura, 1995; Welch and Pandey, 2005; Fuchs-Kittowski and Kohler, 2005; McAffe, 2006; Wagner, 2004; Lee et al., 2005) 


\subsubsection{Adoption and management}

Some researchers have analyzed factors enabling positive relationship between productivity and access to information. More informed managers are better able to make higher quality decisions, are more likely to have developed good managerial skills and have more political manoeuvrability (Marschak and Radner, 1972; Galbraith, 1973).

Other research identified that access to information improves handling recurrent problems, dealing with difficult professional situations, enhances effective knowledge transfer, creates support from experts in accomplishing managerial goals or promotes structural diversity that shortens the path to different networks (Szulanski, 1996; Simon, 1991; Clark, 1996; Crampton, 2001; Burt, 1992; Hansen, 2002).

Other managerial factors, such as IT value, IT risk, IT investment decisions, privacy and security of systems, public expectation, vertical and horizontal integration, radical change, barriers to adoption, and red tape are expected to be addressed before the implementation of Web 2.0 technologies (Chircu and Hae-Dong Lee, 2003; Caudle et al., 1991; Gil-Garcia et al., 2005; Kawalek and Wastall, 2005; Tan et al., 2005; Thong et al., 2000) 


\subsubsection{Adoption process}

According to Rogers (1995), the adoption is an innovation - a decision process which leads to adoption. The idea that adopting an innovation is a decision process is contained in the definition of innovation adoption as a "process by which an innovation is communicating through the certain channels over time among the members of a social system"' (Rogers, 1995).

Spence (1994) analyzed that the adoption process goes through five sequential stages: awareness, interest, evaluation, trial, adoption or rejection (Figure 3).

Figure 3: The adoption process (taken form the source: Spence, 1994)

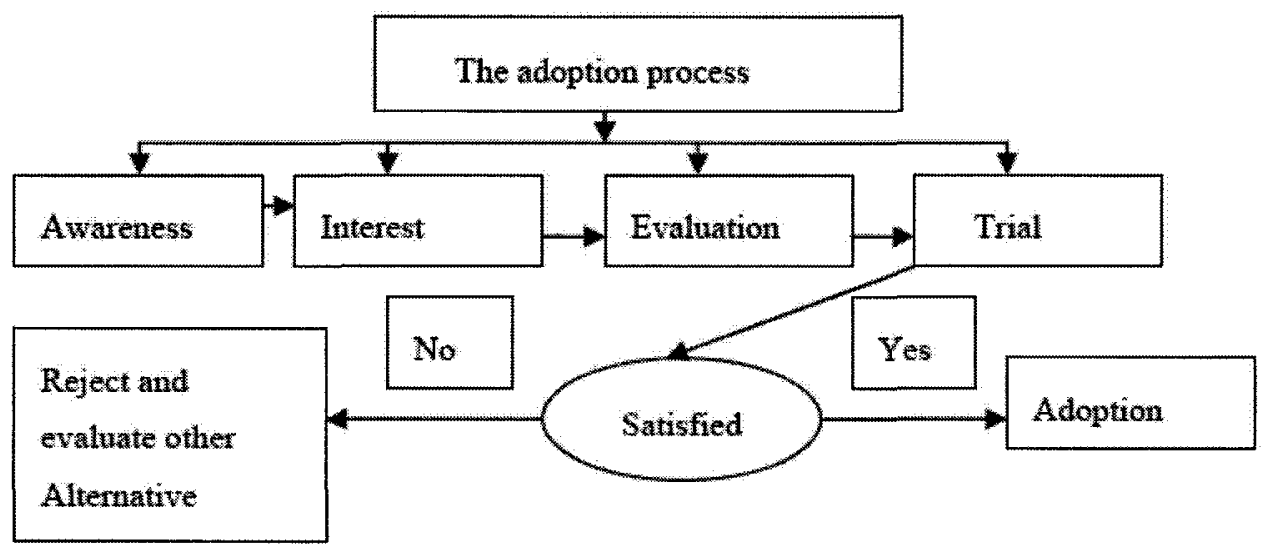




\subsection{Summary}

Web 2.0 technologies bring several changes to the government, which combined are changing the culture of the workplace. Using Web 2.0 collaboration tools will bring some changes into the organizational culture that will have an impact on employee satisfaction and commitment to use these tools. Many researchers, studying public satisfaction, focused their research around employee satisfaction and commitment in the workplace. The literature search resulted in no other studies conducted on the relationship and behaviour of employees while adopting Web 2.0 technologies in the Canadian Government.

Table 1: Key highlights from the literature review

\begin{tabular}{|l|l|l|}
\hline Stream & Key highlights of the stream & Key references \\
\hline $\begin{array}{l}\text { Web 2.0 } \\
\text { technology } \\
\text { tools }\end{array}$ & Broad collection of recent trends in Internet & Hernon (1998) \\
& technologies and business models & O'Reilly (2005) \\
& User created content, lightweight technology, service \\
based access, shared revenue models & Moir (2006) \\
RSS, Wiki, Blogs, Open APIs, Podcast, AJAX, & GTEC 2007 \\
& $\begin{array}{l}\text { Mashups } \\
\text { Social Networks, Collective intelligence, social } \\
\text { bookmarking, user driven ratings, open access content }\end{array}$ & \\
& & \\
\hline
\end{tabular}




\begin{tabular}{|c|c|c|}
\hline Stream & Key highlights of the stream & Key references \\
\hline $\begin{array}{l}\text { Adoption of } \\
\text { Web } 2.0 \text { in } \\
\text { the } \\
\text { Government }\end{array}$ & $\begin{array}{l}\text { Internet as a platform for political disclosure, power of } \\
\text { new e-democracy programs, power of easy scalable } \\
\text { network, the power of "long tail" } \\
\text { Citizen / customer service satisfaction, relationship } \\
\text { among service quality, trust and confidence, factors } \\
\text { influencing trust across public organizations; } \\
\text { Employee satisfaction and } \\
\text { commitment, employees surveys, } \\
\text { public sector studies }\end{array}$ & $\begin{array}{l}\text { Chadwick (2008), } \\
\text { Anderson(2006); } \\
\text { EKOS Research } \\
\text { (2002), } \\
\text { AAFC(2008); } \\
\text { MORI(2003); } \\
\text { Schmidt(2004); } \\
\text { Vieira(2002); }\end{array}$ \\
\hline $\begin{array}{l}\text { Employees } \\
\text { Engagement } \\
\text { to use Web } \\
2.0 \\
\text { Technologies }\end{array}$ & $\begin{array}{l}\text { Adoption at workplace: theory of diffusion of } \\
\text { innovation; relevant factors to adoption: relative } \\
\text { advantage, complexity, compatibility, trust, image, } \\
\text { management capacity, understanding the technology; } \\
\text { Adoption and management: informed managers make } \\
\text { higher quality decisions, access to information } \\
\text { improves handling current problems, barriers to } \\
\text { adoption, red tape } \\
\text { Adoption process:" is a process by which an } \\
\text { innovation is communicating through the certain } \\
\text { channels over time among the members of a social } \\
\text { system". }\end{array}$ & $\begin{array}{l}\text { Rogers (1995), } \\
\text { Carter and } \\
\text { Belanger(2005); } \\
\text { Galbraith(1973), } \\
\text { Hansen(2002), } \\
\text { Thong et al.(2000), } \\
\text { Spence(1994) }\end{array}$ \\
\hline
\end{tabular}




\section{RESEARCH METHOD}

This chapter is organized into three sections. The first section explains the theoretical background for our study method. The second section describes the unit of analysis, identifies the study period and sample selection. The last section identifies the steps undertaken in the case-study analysis.

\subsection{Theoretical Framework}

This research focuses on identifying the key factors that affect successful Web 2.0 adoption within the public sector in Canada. Adoption is considered as the last stage of the adoption process chart according to Spence (1994). We will consider an adoption of Web 2.0 tools to be successful when the process into which the new technology is integrated lasts and it is not shut down. We will use a qualitative approach for this exploratory research, supported by case study analyses, interviews, surveys and academic literature.

Qualitative research is considered appropriate for study of a new phenomenon, such as Web 2.0. According to Ebrahim et al. (2003), an exploratory method is required to 
identify technological and organizational issues for e-government adoption. Zikmund (1994) and Yin (2003) both used exploratory research to clarify and define the nature of the problem.

Eisenhardt (1989) and Lam (2005) used case-study analysis for exploratory study. We will use multiple case-study analysis to identify diverse factors that affect adoption.

According to Yin (2003), interviews are used to obtain in-depth views and experiences of knowledgeable individuals. Interviewing at least eight people tended to reach a point of data saturation. We have interviewed the individuals involved in eight different web project applications, and have also found that the data from the final interviews was yielding very little new information.

Research related to adoption of Web 2.0 technologies in the government attempts to identify similarities or differences in attributes that explain adoption of e-government, use of e-government, adoption of Information and Communication Technologies (ICT), and IT adoption in the government. In addition, we will use other academic literature about innovations to support our thesis. 


\subsection{Unit of Analysis, Study Period and Sample Selection}

Government leaders are experimenting with new IT models using Web 2.0 technologies. More frequently these models are used more for internal than for external purposes. Therefore, for our research, we used as a unit of analysis the government department intranet web site using types of new collaboration tools.

Based on Tim O'Reilly definition of Web 2.0 in 2005 , we considered all government internal web sites created between 2005 and 2008 .

Two main types of collaboration tools are considered. The first is a "wiki" tool and the second is a "blog". In the sample selection, each application must have implemented at least one of these main tools.

\subsection{Research Method}

The following steps were undertaken in this research:

\section{Phase I: Preliminary research}

1. Identify IT managers interviewees through referrals.

2. Conduct preliminary interviews with IT managers.

a. Identify sample projects. 
b. Identify reasons for non adoption or adoption.

\section{Phase II: Research sample}

1. Define categories for motivation to adopt collaborative Web 2.0 tools.

2. Select theoretical perspective.

3. Identify main research questions.

4. For each interviewed group identify categories for motivation and generate insights. Conduct follow-up interviews, as required.

5. Categorize samples based on motivation.

6. Identify the factors related to successful adoption of the innovation web tools.

7. Identify the factors that make adoption challenging.

8. Identify the best practices needed for the successful adoption of Web 2.0 tools in the government departments.

9. Develop propositions and link them to the literature.

\section{Phase I: Preliminary research}

\section{Identify IT managers interviewees through referrals}

By identifying IT project managers who considered, had knowledge or had some working experience with adoption of Web 2.0 technologies, we could identify people to interview, projects to consider or collaboration tools used or adopted in projects, 


\section{Conduct preliminary interviews with IT managers}

\section{2a. Identify sample projects}

We identified eight intranet web applications using Web 2.0 tools as a sample for the research. For each web application, we identified the team of representatives to be interviewed.

\section{2b. Identify reason for non adoption or adoption}

By interviewing IT personnel, such as IT security, IT managers and IT application developers, identify reasons for non adoption, or adoption of collaboration tools. During the meetings with IT security personnel, the researcher assessed the risks to implement collaboration technologies into internal web sites.

\section{Phase II: Research sample}

\section{Define categories for motivation to adopt collaborative Web 2.0 tools}

In this context, an ultimate objective for the Canadian government is to build democratic citizenship while strengthening the confidence and trust of citizens. It is recognized that this is done by service improvement and human resource modernization. To analyze some performance issues of this challenge, many researchers used the key building blocks similar to the private sector models (Heintzman and Marson, 2005). 
Linking the key priorities for public and private sectors, we should get the fundamental objectives for motivation of public management. McKinsey's global annual survey on Web 2.0 (McKinsey, 2008) used three categories of motivation for using Web 2.0 technologies and the following examples of the usage:

- Internal use: Managing knowledge, Fostering collaboration across the government department, Enhancing company culture, Developing products or services, Internal recruiting

- Interfacing with clients: Improving client service, Acquiring new clients in existing Governments, Getting client participation in project development, Letting clients interact, Providing for other client interactions

- Interfacing with partners / suppliers: Achieving better integration with suppliers, Tapping network of experts, Lowering purchasing cost, Getting supplier participation, Carrying out the other partner/supplier processes

\section{Select theoretical perspective}

Gichoya (2005) and others (Khaled, 2003; Mugonyi, 2003) identified a framework for categorizing key factors in the implementation of information and communication 
technologies in government. We use categorizing key factors into factors for success (drivers and enablers) and factors for failure (barriers and inhibitors).

The best way to achieve the successful implementation is to eliminate all factors for failure and support all factors for success. Clokwork (2004) suggests that implementation of best practices harvested from a review of successful applications is required to increase the chances of success.

Caudle (1991) identified difficulties from different management levels to implement new IT. Other barriers to adoption were identified, such as risk, security, resistance, organization diversity, privacy and confidentiality, fear of loosing job, sharing responsibility, organizational climate, etc. (Carter and Belanger, 2005; Layne and Lee, 2001; Schildt et al, 2005).

\section{Identify main research questions}

We considered questions from these three main categories:

1. What are the main drivers that encourage or reinforce the successful implementation of new web tools? 
2. What can you consider as barriers that hindered or could stop the adoption of Web 2.0 technology?

3. What were your actions that help overcome potential barriers that would restrict the successful implementation of Web 2.0 tools?

\section{For each interviewed groups identify categories for motivation and generate insights. Conduct follow-up interviews, as required.}

For each web application in the sample, data was collected from interviewing each group as the representative of that sample. The groups were asked a number of questions related to these subjects: motivation, success factors, failure factors, and risk. The entries of collected data were recorded. A description of each web application was identified. The entries recorded the following data:

- Name of the government organization / group hosting the web application

- Name of the web site

- Purpose for the web site

- Web 2.0 technology used

- Was the web site secure

- Usage (adoption) of the website

- Factors leading to successful adoption 
- Barriers identified to the implementation

- Lessons learned from each group

\section{Categorize samples based on motivation}

Based on three categories for usage (Internal, Interfacing with clients, Interfacing with partners), each web application was categorized by a description for motivation.

\section{Identify the factors related to successful adoptions of the innovation web tools}

From the collected data, all success factors were distinguish and recorded. Successful adoption is considered one form Spence's Adoption process chart in Figure 3. We recognized success factors as those occurrences in which presence or absence of the factor is seen to determine the successful Web 2.0 adoption (Gichoya, 2005).

First, from data collection we distinguished and recorded the driving factors, that is those factors that encourage or reinforce the successful implementation of web tools, such as vision, strategy, external pressure, rising client expectation, technological change, management support, etc.

7. Identify the factors that make adoption challenging 
From the collected data, barriers causing difficult implementation were realized and recorded. We have distinguished these factors as those for which occurrences constrain or hinder the adoption of new Internet tools. For example, these factors include finance, skilled personnel, leadership styles, culture, bureaucracy, and attitudes.

\section{Identify the best practices needed for the successful adoption of Web 2.0 tools in government departments}

From the collected data, we identified two types of active elements present during adoption. The first type, "enabler", were actions which helped overcome the potential barriers, such as effective project, coordination, good practice, etc.

The second types, "inhibitors", do not have to prevent adoption but they do restrict successful implementation of Web 2.0 tools and they prevent advancement of the applications.

We linked literature to our results and created a list of best practices needed for successful adoption of Web 2.0 tools.

\section{Develop propositions and link them to literature}

The following steps were taken to develop propositions: 
1. Factors were identified and recorded. We chose only factors with the highest occurrences.

2. Distinguished best practices were compared with the literature and other casestudies, and were linked to the motivation aspects of adoption.

3. Based on the literature review, the explanatory approach to motivation identified related factors. Results were revised again and finally, from each relationship between factors and motivation, we created a proposition.

4. Based on the results, the final adoption model was developed. The model identifies the drivers of staff commitment to use new technology, as well as the action taken to support these drivers and finally, the relationship between factors and motivation. 


\section{RESEARCH RESULTS}

This chapter is organized into five sections. The first section identifies the eight research samples. The second section illustrates eight case studies from the sample. The third section describes case studies for each sample application. The fourth section identifies factors from case studies having a positive impact on the adoption of new Internet technologies in government. The last section identifies factors having a negative impact on adoption.

\subsection{PHASE I - Preliminary Research}

\section{Preliminary interviews}

From referrals, we indentified the senior IT managers of different government departments and asked them these questions:

1. Have you used in any of your projects any type of Web 2.0 collaboration tools? If yes, how successful you are using these tools? If no, what is preventing you from using these tools?

2. Has your department implemented any type of wikis or blog for internal communication?

3. Do you know of any other uses of Web 2.0 collaboration tools within the Government of Canada? 
The interviewees were a selection of senior application developers, application development managers, application architects, and IT security representatives.

Our result indicated that about $70 \%$ IT managers were not confident to implement or use any kind of Web 2.0 collaboration technologies. Most managers were concerned about security, privacy and copyright issues after implementation of collaboration tools. About $20 \%$ of managers did not know about the new technologies. We noted about $10 \%$ of managers have implemented some new collaboration tools in their projects, or used these technologies in their internal intranet applications. We understood that most of these applications were in the trial stage. We identified eight "early adopters" and considered their web application for our sample in Phase II.

\section{Government security policies}

After identification that security was the main drawback from using collaboration technologies in government applications, we interviewed the representatives of the IT Security department in one government agency. Having considered the nature of collaboration tools of exposing information on the web site in a peer-to-peer environment, IT security representatives identified that the proper risk management needed to be in place. Because identifying, managing and preventing risk is an essential part of each IT application, applications using collaboration technologies will not be different from others. 
To conclude our investigation about concerns related to Web 2.0 technologies, we explored the following existing government policies, acts and standards: Canadian Charter of Rights and Freedoms, Privacy Act, Access to Information Policies, Government Security Policy, Management of Information Technology Security, and Information and Technology Standards. With appropriate application of existing laws and regulations, we did not find any policy preventing the implementation and use of Web 2.0 technologies in government applications.

\subsection{PHASE II - Research Sample}

The sample, identified from Phase I, included eight government intranet web sites which integrated into their pages at least one type of collaboration software, namely, wiki pages or blogs. The applications are mostly created by IT groups, service branch or communication groups with the purpose of managing information technology knowledge, discussing topics within the project team, or collaborating on different projects.

\section{Application usage}

Table 2 identifies the eight applications under study which are used internally within the departments. Six out of eight applications were used for communication among the group members and two applications were used for the internal communication with clients or partners. One application was created for collaboration among government 
employees and their clients, and another application was used for collaboration among government employees and their partners.

\section{Secure data}

Three out of eight intranet applications in the sample did not use any authentication for accessing the application data. Other applications used authentication against user names and passwords with valid email addresses. None of the applications used data encryption or Public Key Infrastructure (PKI) credentials as part of the security architecture. 
Table 2: Research sample of web applications used by Canadian governments

\begin{tabular}{|c|c|c|c|c|c|}
\hline \# & Web site name & $\begin{array}{l}\text { Application } \\
\text { type/purpose }\end{array}$ & $\begin{array}{l}\text { Interviewed } \\
\text { people with } \\
\text { roles }\end{array}$ & $\begin{array}{l}\text { Authentication } \\
\text { needed }\end{array}$ & $\begin{array}{l}\text { Web } 2.0 \\
\text { tools - } \\
\text { used } \\
\text { templates } \\
\end{array}$ \\
\hline 1 & Wiki application & $\begin{array}{l}\text { Intranet - } \\
\text { Internal use }\end{array}$ & $\begin{array}{l}\text { Project } \\
\text { Manager, Main } \\
\text { Contributor }\end{array}$ & No & Media Wiki \\
\hline 2 & Wiki application & $\begin{array}{l}\text { Intranet - } \\
\text { Internal use }\end{array}$ & $\begin{array}{l}\text { Project } \\
\text { Manager, } \\
\text { Project Leader }\end{array}$ & Yes & XWiki \\
\hline 3 & Wiki application & $\begin{array}{l}\text { Intranet - } \\
\text { Internal use }\end{array}$ & $\begin{array}{l}\text { Project Leader, } \\
\text { Main } \\
\text { Developer }\end{array}$ & Yes & TWiki \\
\hline 4 & $\begin{array}{l}\text { Java application } \\
\text { using blogs }\end{array}$ & $\begin{array}{l}\text { Extranet - } \\
\text { Interfacing } \\
\text { with clients }\end{array}$ & $\begin{array}{l}\text { Project } \\
\text { Manager, Main } \\
\text { Developer }\end{array}$ & Yes & $\begin{array}{l}\text { Blogs - } \\
\text { unknown }\end{array}$ \\
\hline 5 & Blogging database & $\begin{array}{l}\text { Intranet - } \\
\text { Internal use }\end{array}$ & $\begin{array}{l}\text { Application } \\
\text { Owner }\end{array}$ & No & $\begin{array}{l}\text { BlogSphere } \\
\text { from } \\
\text { OpenNTF.org }\end{array}$ \\
\hline 6 & $\begin{array}{l}\text { Project application } \\
\text { using wiki tools }\end{array}$ & $\begin{array}{l}\text { Extranet - } \\
\text { Interfacing } \\
\text { with partners }\end{array}$ & $\begin{array}{l}\text { Project } \\
\text { Manager, } \\
\text { Chief/ } \\
\text { Application } \\
\text { Architecture }\end{array}$ & Yes & TikiWiki \\
\hline 7 & $\begin{array}{l}\text { Blogging } \\
\text { application }\end{array}$ & $\begin{array}{l}\text { Intranet - } \\
\text { Internal use }\end{array}$ & $\begin{array}{l}\text { Application } \\
\text { Owner }\end{array}$ & No & $\begin{array}{l}\text { BlogSphere } \\
\text { from } \\
\text { OpenNTF.org }\end{array}$ \\
\hline
\end{tabular}




\begin{tabular}{|c|c|c|c|c|c|}
\hline$\#$ & Web site name & $\begin{array}{l}\text { Application } \\
\text { type/purpose }\end{array}$ & $\begin{array}{l}\text { Interviewed } \\
\text { people with } \\
\text { roles }\end{array}$ & $\begin{array}{c}\text { Authentication } \\
\text { needed }\end{array}$ & $\begin{array}{l}\text { Web 2.0 } \\
\text { tools- } \\
\text { used } \\
\text { templates }\end{array}$ \\
\hline 8 & $\begin{array}{l}\text { Blogging } \\
\text { application }\end{array}$ & $\begin{array}{l}\text { Intranet - } \\
\text { Internal use }\end{array}$ & $\begin{array}{l}\text { Project } \\
\text { Manager }\end{array}$ & Yes & $\begin{array}{l}\text { Blog - } \\
\text { uknown }\end{array}$ \\
\hline
\end{tabular}




\subsection{Case Studies}

\section{Case 1: Wiki application}

Table 3 represents the case of the Wiki application. In order to share the knowledge and encourage collaboration within the department, the communication group implemented an internal knowledge management system based on Web 2.0 technologies using a Media Wiki template (www.mediawiki.org).

The representatives of the web site did not express any concem about data security. A group of dedicated people keep creating the content of the web site. To contribute to wiki pages or upload a file, users must first create their accounts with a user name and password and thereafter, they log in with their accounts. Pages are checked regularly for their content. 
Table 3: Case 1 - Wiki application

\begin{tabular}{|c|c|}
\hline $\begin{array}{l}\text { Purpose of the web } \\
\text { site }\end{array}$ & $\begin{array}{l}\text { Knowledge sharing, managing knowledge, fostering } \\
\text { collaboration across departments }\end{array}$ \\
\hline Context & $\begin{array}{l}\text { Knowledge -intensive } \\
\text { Sharing data } \\
\text { Collaborative culture }\end{array}$ \\
\hline User roles & Users produce wiki documents or sections \\
\hline Authentication & $\begin{array}{l}\text { No authentication needed } \\
\text { Open as an intranet application }\end{array}$ \\
\hline Benefits & $\begin{array}{l}\text { Centralized documentation } \\
\text { Knowledge creation } \\
\text { Desire for peer recognition } \\
\text { Increase collaboration }\end{array}$ \\
\hline Risks & $\begin{array}{l}\text { Low participation } \\
\text { Ownership of information published on the wiki }\end{array}$ \\
\hline Lesson learned & $\begin{array}{l}\text { Dissemination of departmental documents } \\
\text { Users are involved in the quality assurance peer-reviews and } \\
\text { comments }\end{array}$ \\
\hline
\end{tabular}

\section{Case 2: Wiki application}

Table 4 represents the case of another Wiki web application. The IT group adopted new collaboration tools for internal communication among its members. The application is also used as a central repository for project management documentation. The web application is based on a customized version of the XWiki template (www.xwiki.org). 
Only the group members can access the web site. Authentication is done by logging in with a user name and password that are matched with the user profile stored in the database. Managers are responsible for the content of the web site.

Table 4: Case 2 - Wiki web site

\begin{tabular}{|l|l|}
\hline $\begin{array}{l}\text { Purpose of the web } \\
\text { site }\end{array}$ & $\begin{array}{l}\text { Internal communication secure site used by an IT group as a } \\
\text { repository for knowledge sharing, managing and administration } \\
\text { of project management document }\end{array}$ \\
\hline Context & $\begin{array}{l}\text { Project documentation } \\
\text { Status reports } \\
\text { Bug reports } \\
\text { Change requests } \\
\text { Business requirement documents } \\
\text { Group calendar }\end{array}$ \\
\hline User roles & $\begin{array}{l}\text { Managers create project documentation } \\
\text { Developers and testers to produce reports } \\
\text { Business analysts produce documentation }\end{array}$ \\
\hline Authentication & User name and password, users have different access rights \\
\hline Benefits & $\begin{array}{l}\text { Centralized place for project documents } \\
\text { Used instead of emails } \\
\text { Save time to look for documents }\end{array}$ \\
\hline Lesson learned & $\begin{array}{l}\text { Low participation } \\
\text { Regular usage }\end{array}$ \\
\hline
\end{tabular}




\section{Case 3: Wiki application}

Table 5 illustrates the case of the Wiki application. The IT web development group used the TWiki template to build the application (www.twiki.org). The group used the application for knowledge sharing and document repository.

Access to the web application is restricted to the members of the Web Development group. All members are responsible for creating and maintaining the content of the web site.

Table 5: Case 3 - Wiki web site

\begin{tabular}{|l|l|}
\hline $\begin{array}{l}\text { Purpose of the web } \\
\text { site }\end{array}$ & $\begin{array}{l}\text { Internal application for the IT group knowledge sharing, } \\
\text { licence, service agreements, best practices, fostering } \\
\text { collaboration within the group }\end{array}$ \\
\hline Context & $\begin{array}{l}\text { IT documentation related to the group work } \\
\text { Depository of service agreements } \\
\text { Best practices for the web development and support }\end{array}$ \\
\hline User roles & All users are participants and produce wiki pages \\
\hline Authentication & Need user name and password \\
\hline Benefits & $\begin{array}{l}\text { Awareness of everybody's work } \\
\text { Knowledge creation } \\
\text { Facilitation of learning for newcomers }\end{array}$ \\
\hline Risks & $\begin{array}{l}\text { Low participation } \\
\text { Management support lacking }\end{array}$ \\
\hline Lesson learned & Improving quality of management process \\
\hline
\end{tabular}




\section{Case 4: Java application using blogs}

Table 6 shows the case of the Java application using blogs. The secured intranet web application is used as a cross-agency application to promote more collaboration and knowledge sharing among research experts and health officers. The application uses a blogging system.

The representatives of the web site expressed concern about the sensitivity of posted data. The sensitivity level of all data is recorded and later, data is archived or deleted from the system. Pages are checked regularly for content. 
Table 6: Case 4 - Java application with blogs

\begin{tabular}{|l|l|}
\hline $\begin{array}{l}\text { Purpose of the web } \\
\text { site }\end{array}$ & $\begin{array}{l}\text { Application Interfacing with clients - knowledge sharing, } \\
\text { getting clients participation, letting clients interact, improving } \\
\text { client service, data moderation }\end{array}$ \\
\hline Context & $\begin{array}{l}\text { Database data related to the Quarantine application } \\
\text { Experts and participants blogs and comments }\end{array}$ \\
\hline User roles & $\begin{array}{l}\text { Research experts and quarantine officers participate in blogs } \\
\text { and comments. } \\
\text { Managers decide when to delete sensitive data in blogs }\end{array}$ \\
\hline Authentication & $\begin{array}{l}\text { Participants provide their user names and passwords, which are } \\
\text { stored in their user profiles together with their email address, } \\
\text { phone number and address }\end{array}$ \\
\hline Benefits & $\begin{array}{l}\text { Information sharing } \\
\text { Improving participation } \\
\text { Better decision making process }\end{array}$ \\
\hline Risks & $\begin{array}{l}\text { Abuse of sensitive data in blogs } \\
\text { Low participation } \\
\text { Usability for personal purpose } \\
\text { Who is responsible for data signature? }\end{array}$ \\
\hline
\end{tabular}




\section{Case 5: Blogging application}

Table 7 provides the case of a Blogging application. The internal non-secured application is accessible to all members. Blogs are written and posted by one person.

Other people can react and write their comments. Participants create their user name and password with no authentication needed. The application was created from the BlogShere template (OpenNTF.org).

\section{Table 7: Case 5 - Blogging application}

\begin{tabular}{|l|l|}
\hline $\begin{array}{l}\text { Purpose of the web } \\
\text { site }\end{array}$ & $\begin{array}{l}\text { The purpose of the application is to provide tips and news to the } \\
\text { IT developer community and to anyone else who is interested }\end{array}$ \\
\hline Context & $\begin{array}{l}\text { Subjects dealing with development software created as blogs } \\
\text { Comments from other developers }\end{array}$ \\
\hline User roles & $\begin{array}{l}\text { Readers of blogs } \\
\text { Contributors to the comment section }\end{array}$ \\
\hline Buthentication & $\begin{array}{l}\text { No authentication needed } \\
\text { expert advice } \\
\text { Promote collaboration } \\
\text { Enhance reputation for contributors } \\
\text { Experts advice } \\
\text { Easy to use application } \\
\text { Fostering collaboration across departments }\end{array}$ \\
\hline Risks & $\begin{array}{l}\text { Low participation } \\
\text { Lesson learned }\end{array}$ \\
\hline
\end{tabular}




\section{Case 6: Project application using wikis}

Table 8 identifies the case of the project application using wiki tools. The secured extranet web application was created for the project site users to access the knowledge database, collaborate with colleagues, clients and partners. Application had implemented a wiki tool based on the TikiWiki open source software (www.tikiwiki.org).

Table 8: Case 6-Project application using wikis

\begin{tabular}{|c|c|}
\hline $\begin{array}{l}\text { Purpose of the web } \\
\text { site }\end{array}$ & $\begin{array}{l}\text { Interfacing with partners - Application was created for the } \\
\text { project site users as an knowledge database, knowledge sharing } \\
\text { among community of developers, client users and experts, } \\
\text { improving client services, getting partner participation, letting } \\
\text { client interact, providing for other client interaction }\end{array}$ \\
\hline Context & $\begin{array}{l}\text { Database of related data } \\
\text { Collaboration documentation } \\
\text { Project documents }\end{array}$ \\
\hline User roles & $\begin{array}{l}\text { Contributors to database data } \\
\text { Contributors to discussions } \\
\text { Data users and administrators }\end{array}$ \\
\hline Authentication & Secured extranet application authenticating each user \\
\hline Benefits & $\begin{array}{l}\text { Many partner collaboration } \\
\text { Development forums } \\
\text { Reduction in internal emails sent } \\
\text { Knowledge creation }\end{array}$ \\
\hline Risks & $\begin{array}{l}\text { Sharing sensitive data } \\
\text { Lack of participation }\end{array}$ \\
\hline Lesson learned & No official organizational support for OSS \\
\hline
\end{tabular}




\section{Case 7: Blogging application}

Table 9 illustrates the case of the internal non-secured application using blogs. Blogs are written and posted by one person. Other employees can write their comments.

Participants create their user name and password with no authentication needed. The application was created from the BlogShere template (OpenNTF.org).

\section{Table 9: Case 7 - Blogging application}

\begin{tabular}{|l|l|}
\hline $\begin{array}{l}\text { Purpose of the web } \\
\text { site }\end{array}$ & $\begin{array}{l}\text { Blog is focused on one person's experience, tips and best } \\
\text { practices regarding the work on building an automated tool for a } \\
\text { search engine used by that government department. }\end{array}$ \\
\hline Context & $\begin{array}{l}\text { Technical issues } \\
\text { Business information } \\
\text { Best practices } \\
\text { Personal views } \\
\text { Comments }\end{array}$ \\
\hline User roles & $\begin{array}{l}\text { Contributors to database data } \\
\text { Contributors to discussions } \\
\text { Data users } \\
\text { Data administrators }\end{array}$ \\
\hline Authentication & Non secured intranet application \\
\hline Benefits & $\begin{array}{l}\text { Sharing knowledge and experience } \\
\text { Knowledge creation }\end{array}$ \\
\hline Risks & $\begin{array}{l}\text { Legal risk / HR risk } \\
\text { Lack of participation }\end{array}$ \\
\hline Lesson learned & $\begin{array}{l}\text { No official organizational support for blogging or using wiki } \\
\text { applications }\end{array}$ \\
\hline
\end{tabular}




\section{Case 8: Blogging application}

Table 10 represents the case of the blogging application. The application is used to encourage discussion of different technical topics and to foster departmental collaboration.

The web site can be accessed only by the group members. Authentication is done by logging in with a user account that is matched with the user profile. Managers are responsible for the content of the web site.

\section{Table 10: Case 8 - Blogging application}

\begin{tabular}{|l|l|}
\hline $\begin{array}{l}\text { Purpose of the web } \\
\text { site }\end{array}$ & $\begin{array}{l}\text { Blog site is used as an open forum for the exchange of } \\
\text { information, ideas, opinions, and other thoughts relating to the } \\
\text { group's community. }\end{array}$ \\
\hline Context & $\begin{array}{l}\text { Conversation and discussions about technical issues } \\
\text { Sharing photos } \\
\text { Personal views }\end{array}$ \\
\hline User roles & $\begin{array}{l}\text { Contributors to discussion issues } \\
\text { Readers } \\
\text { Administrators of the web site }\end{array}$ \\
\hline Authentication & $\begin{array}{l}\text { Secured intranet application, authentication against the user } \\
\text { department profile }\end{array}$ \\
\hline Benefits & $\begin{array}{l}\text { Sharing knowledge, experience and personal views } \\
\text { Sharing photos }\end{array}$ \\
\hline Risks & $\begin{array}{l}\text { Legal risk/HR risk } \\
\text { Lack of participation }\end{array}$ \\
\hline
\end{tabular}




\subsection{Factors Having a Positive Impact on Adoption of Web 2.0}

Table 11 shows the drivers identified and obtained from the web site representatives in the sample. We identified 13 factors that have a positive impact on adoption collaboration technology in the internal government web sites. For each factor, the table provides the number of occurrences of that factor in the sample and its percentile number. Identified factors are represented by phrases, description and key words. 
Table 11: Main drivers to use collaboration tools and participate in collaboration

\begin{tabular}{|c|c|c|c|c|}
\hline Rank & $\begin{array}{l}\text { \# }(\%) \text { of } \\
\text { occurrences }\end{array}$ & Drivers & Description of drivers & Key words \\
\hline 1 & $7(87.5 \%)$ & Sharing knowledge & $\begin{array}{l}\text { Need for collaboration } \\
\text { Understand others' work }\end{array}$ & $\begin{array}{l}\text { Sharing } \\
\text { knowledge, } \\
\text { collaboration }\end{array}$ \\
\hline 2 & $6(75 \%)$ & Knowledge creation & $\begin{array}{l}\text { Experts at work need to } \\
\text { share their findings with } \\
\text { others } \\
\text { Posted articles from the } \\
\text { experts }\end{array}$ & $\begin{array}{l}\text { Knowledge } \\
\text { sharing, experts, } \\
\text { new information }\end{array}$ \\
\hline 3 & $6(75 \%)$ & $\begin{array}{l}\text { Enhanced } \\
\text { participation of } \\
\text { employees }\end{array}$ & $\begin{array}{l}\text { Encourage communication } \\
\text { between blog owner and } \\
\text { community } \\
\text { Support users to } \\
\text { disseminate documents in } \\
\text { wiki formats }\end{array}$ & $\begin{array}{l}\text { Participation in } \\
\text { communication, } \\
\text { document } \\
\text { dissemination, } \\
\text { encouragement to } \\
\text { participate }\end{array}$ \\
\hline 4 & $6(75 \%)$ & Make work easier & $\begin{array}{l}\text { Relevant information for } \\
\text { the work, updated } \\
\text { knowledge, easy } \\
\text { dissemination of work }\end{array}$ & $\begin{array}{l}\text { Found relevant } \\
\text { information, } \\
\text { updated } \\
\text { knowledge, } \\
\text { easy access, } \\
\text { shared documents }\end{array}$ \\
\hline 5 & $5(62.5 \%)$ & Job satisfaction & $\begin{array}{l}\text { Professionals will } \\
\text { communicate and } \\
\text { collaborate their ideas or } \\
\text { invite reactions to their } \\
\text { postings }\end{array}$ & $\begin{array}{l}\text { Need to share } \\
\text { knowledge, } \\
\text { new ideas created, } \\
\text { challenge from } \\
\text { others }\end{array}$ \\
\hline 6 & $4(50 \%)$ & $\begin{array}{l}\text { Competent } \\
\text { information }\end{array}$ & $\begin{array}{l}\text { Find the competent } \\
\text { information and task } \\
\text { expertise }\end{array}$ & $\begin{array}{l}\text { Expert advice, } \\
\text { competent } \\
\text { information }\end{array}$ \\
\hline 7 & $4(50 \%)$ & Better learning & $\begin{array}{l}\text { Facilitating the learning } \\
\text { process for newcomers } \\
\text { Less duplicated material }\end{array}$ & $\begin{array}{l}\text { Centralized } \\
\text { documentation, } \\
\text { learning material } \\
\end{array}$ \\
\hline 8 & $4(50 \%)$ & $\begin{array}{l}\text { Positive perception } \\
\text { of senior manager }\end{array}$ & $\begin{array}{l}\text { Senior management can } \\
\text { overview department } \\
\text { trends and issues }\end{array}$ & $\begin{array}{l}\text { Senior } \\
\text { management, } \\
\text { departmental issues }\end{array}$ \\
\hline 9 & $4(50 \%)$ & $\begin{array}{l}\text { Desire for peer } \\
\text { recognition }\end{array}$ & $\begin{array}{l}\text { Growing competition } \\
\text { among independent } \\
\text { bloggers or wiki creators } \\
\text { can lead to recognizing } \\
\text { experts in different IT } \\
\text { subjects }\end{array}$ & $\begin{array}{l}\text { Peer recognition, } \\
\text { recognizing an } \\
\text { expert }\end{array}$ \\
\hline
\end{tabular}




\begin{tabular}{|l|l|l|l|l|}
\hline Rank & $\begin{array}{l}\text { \# (\%) of } \\
\text { occurrences }\end{array}$ & Drivers & Description of drivers & Key words \\
\hline 10 & $3(37.5 \%)$ & $\begin{array}{l}\text { Understanding } \\
\text { employee needs }\end{array}$ & $\begin{array}{l}\text { Posted information from } \\
\text { the employee's shared } \\
\text { insights, employees } \\
\text { contribute to the current } \\
\text { issues or problems }\end{array}$ & Employees' needs \\
\hline 11 & $3(37.5 \%)$ & Enhance reputation & $\begin{array}{l}\text { Earn respect of others } \\
\text { Improve professional status } \\
\text { Improve reputation in the } \\
\text { department }\end{array}$ & $\begin{array}{l}\text { Respect from } \\
\text { others, professional } \\
\text { status, reputation }\end{array}$ \\
\hline 12 & $3(37.5 \%)$ & $\begin{array}{l}\text { Self imposed } \\
\text { quality assurance }\end{array}$ & $\begin{array}{l}\text { Users are involved in the } \\
\text { quality assurance through } \\
\text { ratings, peer-reviews and } \\
\text { comments }\end{array}$ & $\begin{array}{l}\text { Quality assurance, } \\
\text { employee's ratings, } \\
\text { peer reviews }\end{array}$ \\
\hline 13 & $2(25 \%)$ & $\begin{array}{l}\text { A career path that } \\
\text { offers opportunity } \\
\text { for advancement }\end{array}$ & $\begin{array}{l}\text { A career path that offers } \\
\text { opportunity for } \\
\text { advancement }\end{array}$ & Career making \\
\hline
\end{tabular}




\subsection{Factors Having a Negative Impact on Adoption of Web 2.0}

Table 12 shows the barriers identified and obtained from the web site representatives in the sample. We identified 11 factors that have a negative impact on adoption collaboration technology in the government web sites. For each factor, the table provides the number of occurrences of that factor in the sample and its percentile number. Identified factors are represented by phrases, description and key words. 
Table 12: Top barriers to further success of Web 2.0 initiatives

\begin{tabular}{|c|c|c|c|c|}
\hline Rank & $\begin{array}{l}\text { H (\%) of } \\
\text { occurrences }\end{array}$ & Factors & Description & Key words \\
\hline 1 & $6(75 \%)$ & $\begin{array}{l}\text { No support from } \\
\text { department }\end{array}$ & $\begin{array}{l}\text { Organization does not support } \\
\text { implementation of collaboration } \\
\text { tools }\end{array}$ & $\begin{array}{l}\text { No support from } \\
\text { higher } \\
\text { management }\end{array}$ \\
\hline 2 & $5(62.5 \%)$ & Legal risk / HR risk & $\begin{array}{l}\text { Legal risk and HR risk are } \\
\text { associated with the use of Web } \\
2.0 \text { technologies }\end{array}$ & $\begin{array}{l}\text { Licence problem, } \\
\text { legal issues, work } \\
\text { ethics issues, } \\
\text { human resource } \\
\text { issues }\end{array}$ \\
\hline 3 & $4(50 \%)$ & $\begin{array}{l}\text { Ownership of } \\
\text { information } \\
\text { published on the } \\
\text { wiki }\end{array}$ & $\begin{array}{l}\text { Who is the owner of published } \\
\text { information on wiki? }\end{array}$ & $\begin{array}{l}\text { Information } \\
\text { ownership, } \\
\text { copyright }\end{array}$ \\
\hline 4 & $3(37.5 \%)$ & Security issues & $\begin{array}{l}\text { Do we need to worry about } \\
\text { security using wiki } \\
\text { applications? }\end{array}$ & $\begin{array}{l}\text { Security issues not } \\
\text { answered }\end{array}$ \\
\hline 5 & $3(37.5 \%)$ & Data protection & $\begin{array}{l}\text { How will the data published on } \\
\text { collaborative web sites be } \\
\text { protected? }\end{array}$ & Data protection \\
\hline 6 & $2(25 \%)$ & $\begin{array}{l}\text { Appropriate open- } \\
\text { source solution }\end{array}$ & $\begin{array}{l}\text { Problem to evaluate and select } \\
\text { appropriate open-source } \\
\text { solution }\end{array}$ & $\begin{array}{l}\text { Technical solution, } \\
\text { open source, } \\
\text { evaluation }\end{array}$ \\
\hline 7 & $2(25 \%)$ & $\begin{array}{l}\text { Lacking } \\
\text { management } \\
\text { support }\end{array}$ & $\begin{array}{l}\text { Management is afraid to } \\
\text { implement new Internet tools }\end{array}$ & $\begin{array}{l}\text { No-enthusiastic } \\
\text { leadership, no } \\
\text { management } \\
\text { support }\end{array}$ \\
\hline 8 & $2(25 \%)$ & No specials skills & $\begin{array}{l}\text { Organization does not have } \\
\text { special skills to implement Web } \\
2.0 \text { technologies }\end{array}$ & $\begin{array}{l}\text { Skills, Web } 2.0 \\
\text { technologies } \\
\text { implementation }\end{array}$ \\
\hline 9 & $2(25 \%)$ & $\begin{array}{l}\text { Cost saving in } \\
\text { question }\end{array}$ & $\begin{array}{l}\text { Can we expect cost saving by } \\
\text { using collaboration tools? }\end{array}$ & $\begin{array}{l}\text { Cost saving, cost } \\
\text { reduction }\end{array}$ \\
\hline 10 & $1(12.5 \%)$ & IT support & $\begin{array}{l}\text { Who is going to support all new } \\
\text { collaboration applications? }\end{array}$ & $\begin{array}{l}\text { IT support } \\
\text { commitment }\end{array}$ \\
\hline 11 & $1(12.5 \%)$ & $\begin{array}{l}\text { Compatibility with } \\
\text { other applications or } \\
\text { operating systems }\end{array}$ & $\begin{array}{l}\text { Determine compatibility with } \\
\text { other applications or operating } \\
\text { systems }\end{array}$ & $\begin{array}{l}\text { Compatibility with } \\
\text { other application } \\
\text { problem, } \\
\text { compatibility with } \\
\text { operating systems, } \\
\text { storage problems }\end{array}$ \\
\hline
\end{tabular}




\section{DISCUSSION OF RESULTS}

This chapter reviews the results of the study. The content is organized into three sections. The first section identifies the resulting five success factors. The second section presents the highest occurrences of the factors that act as barriers for adoption and identifies the activities needed to overcome these barriers to successfully implement new collaborative technologies in government departments. Finally, the last section contains propositions related to the model, with motivational and organizational factors that affect adoption of Web 2.0 technologies in the government.

\subsection{Success Factors}

From the sample of eight government internal applications, we obtained the set of thirteen factors that were identified as occurrence factors that drive the successful implementation and adoption of Web 2.0 technology. We will continue the approach and identify factors only with the most occurrences.

We identified five factors with the occurrence greater than $50 \%$ (Table 13) as the most important factors that drive employees to use the new collaboration tools: 
- Need for knowledge sharing

- Need for expert knowledge

- Need for communication enhancement

- Making work easier

- Job satisfaction

Table 13: Five of the most important success factors

\begin{tabular}{|l|l|l|l|}
\hline Rank & Occurrences & Factors & Description \\
\hline 1 & $7(87.5 \%)$ & Sharing knowledge & $\begin{array}{l}\text { Need for collaboration } \\
\text { Understand other's work }\end{array}$ \\
\hline 2 & $6(75 \%)$ & $\begin{array}{l}\text { Knowledge } \\
\text { creation }\end{array}$ & $\begin{array}{l}\text { Experts at work need to share their } \\
\text { findings with others } \\
\text { Posted articles from the experts }\end{array}$ \\
\hline 3 & $6(75 \%)$ & Enhanced & $\begin{array}{l}\text { Encourage communication between } \\
\text { communication }\end{array}$ \\
\hline 4 & $6(75 \%)$ & Make work easier & $\begin{array}{l}\text { Support users to disseminate documents } \\
\text { in wiki formats }\end{array}$ \\
& & $\begin{array}{l}\text { Relevant information for the work, } \\
\text { updated knowledge, easy dissemination } \\
\text { of work }\end{array}$ \\
\hline 5 & $5(62.5 \%)$ & Job satisfaction & $\begin{array}{l}\text { Professionals will communicate and } \\
\text { collaborate their ideas or invite reactions } \\
\text { to their postings }\end{array}$ \\
\hline
\end{tabular}


Factor 1: The link between motivation and need for knowledge sharing - what does the literature say?

O'Reilly identifies in his work that man's fundamental desire to connect, communicate and participate are main motivational factors that drive Web 2.0 (O'Reilly, 2005). Among the key six market drivers, he identifies an increased need for collaboration, knowledge sharing, and participating in the user-generated web content.

A stream of researchers has focused on identifying the degree to which the individual believes that there is a need for collaboration. Mostly linked to work benefits (Majchrzak et al., 2006); individuals use collaboration tools to find new solutions to their problems or to look for others' input. Also, an email and other collaboration channels can be used. Using wikis and blogs in the corporate environment can bridge the gap between development of knowledge and a discussion of what was developed, which is very difficult with other media, such as emails.

Many researchers focused their studies on issues anchored around e-government and ICT adoption, such as cooperation between organization and sharing data and knowledge. Historical results indicate that the wide use of communication technology will improve the efficiency, effectiveness, transparency and accountability of government (Warkentin et al. 2002, Al-Shehry et al. 2006). 
Factor 1: The link between motivation and need for knowledge sharing - what does our data say?

The results from our sample indicate that in the most cases, wikis and blogs were used as a new web technology for knowledge sharing and collaboration. Since it came from open source, it was very easy to implement with almost no cost attached. In most cases, middle managers initiated the implementation of wikis and blogs. Their motivation was to find the most effective and efficient way to deal with projects, client needs and partner inputs.

In most cases, the purpose was to test new web tools for collaboration among small groups. The strategy was to keep participants involved and posted regularly. To ensure regularity of posting, a group of designated people was appointed to produce wiki pages or blogs. In only two cases, government employees used the wikis and blogs to communicate with their clients and partners using secure intranet and extranet network. Application users learned from client behaviour. They noted their preferences and adopted them accordingly.

Our respondents stated that among participant benefits derived from using the collaborative web site, was a reduction in emails, better learning, centralized knowledge related to their work, saving time searching documents, etc. It was noted that the traffic 
around wikis and blogs increased with the number of postings and encouragement from management.

Thus, according to our sample, both management and employees are motivated in the workplace to use collaboration tools for knowledge sharing.

Factor 2: The link between motivation and need for knowledge creation - what does the literature say?

Web 2.0 has marked its success in many social, economic and technologic areas. To understand theses successes, Tim O’Reilly (2005) underlined eight core patterns as a key to understanding success in Web 2.0. One of the patterns, harnessing collective intelligence, identifies that the participation and work produced get better the more people use it. Experts are motivated to share their findings with others and thus they contribute to knowledge creation.

Majchrzak's (2006) survey results identified that the benefits of using corporate wiki applications were seen when the wiki was used for collaboration involving tasks requiring novel solutions and the information was created by a credible source. Individuals believed that others possessed the credibility to post expert articles. Tolerance of constructive criticism and willingness to embrace change were found in 
organizations with reasonable level of openness and trust (Kohler, 2005; Lee et al., 2005; Wagner, 2004; McAffee, 2006).

Wikipedia is an example of maximizing impact on individual knowledge creation when participating within a social network. Articles posted from the experts get better; the more experts read and contribute to them.

\section{Factors 2: The link between motivation and knowledge creation - what does our data say?}

The results from eight web sites indicate that only six web applications were used for knowledge creation. Participants of four web sites were encouraged by managers to post their findings, best practices or expert observation and later, provided that this was credible information from field experts, information was re-used by other users to solve problems. Having expert information on line helped managers solve problems quickly, while at the same time it provided them with a list of experts in different fields. This earned reputation among colleagues and managers gave participants motivation to share their findings.

Users from two web sites published new expert information on a weekly basis. Their applications used blogs that gave them the same opportunity as the vast Internet audience - to have one-to-on e-conversations with an audience of many. Both blogging web sites 
were personal blogs that provided the IT community with views on particular technical issues, best practices or activities taken while solving technical problems. Bloggers were motivated by readers' responses in comment sections or by measuring the traffic on the web sites. Besides earning the respect of others, experts found blogging improved their professional status and their reputation in the work place.

Certainly, we could see that the results from case studies gave managers and individuals purpose to share their expert advice. Thus, we can link the motivational factors to the creation of knowledge while using Web 2.0 technologies.

\section{Factor 3: The link between motivation and enhanced communication - what does the literature say?}

Some common Web 2.0 attributes were identified by O'Reilly (2005) and linked to communication encouragement and enhancement. For example, Web 2.0 openness starts with the open source technology and technology standards and grows into an open ecosystem of loosely coupled applications. The openness promotes greater transparency and visibility of how products are developed. Over time, loosely coupled applications will emerge into one solution, which is an example of successful cooperation and communication without any systemic controls. User engagement in communicating their needs and experience while testing the product had significant impact on changing an application into ongoing services. 
In previous research, work benefits were associated with availability of alternative communication channels and challenges initiated by the mass communication media such as trust, intention to use and predictability (Thong et al., 2000; Majchrzak's et al., 2006; Gefen et al, 2002).

Based on the McKinsey global survey (McKensey, 2008) dealing with companies using Web 2.0 technologies, survey results revealed that more companies are focusing on interactions with their customers compared to the last year results. The survey indicated that $78 \%$ of companies used Web 2.0 for fostering collaboration across company lines, $53 \%$ used web tools for interaction with customers and $43 \%$ claimed the use of web technologies for participation with partners and suppliers.

\section{Factor 3: The link between motivation and enhanced communication - what does our data say?}

Most web sites from the sample were created with the purpose of fostering collaboration within a small group of users or across departments. The blog owners encouraged others to contribute to their web site by enabling comment sections to present other views, opinions and knowledge. Communication enhancement was a key strategic success factor for blog applications. The main purpose of the blog owner was to reach the widest 
audience and encourage their online engagement to the proposed subjects in blogs. Individuals found rewarding the fact that they had initiated a network of technical users.

Based on the experience with Web 2.0 technologies in our sample, IT managers noticed a growing demand to use blogs and wikis as the main communication tools with their customers. Two applications from our sample used blog and wiki tools to improve client service by enlisting client participation in communication with the main organization. As a result, many collaboration forums were created to change knowledge, documents and find solutions to problems. Managers were rewarded with successful project endings, improving client services and community involvement in problem solving.

Factor 4: The link between motivation and making work easier - what does the literature say?

Rich user experience is one of the patterns linked to a success in using Web 2.0 (O'Reilly, 2005). Web 2.0 is a platform to not only create information but also reuse user-generated content. This can be done by RSS technologies or mash up tools. Google Maps and MapQuest are two applications that had a dramatic impact on online mapping space.

It is not necessary that wiki and blogs identify solutions to work problems. Results form surveys found that Web 2.0 collaboration tools helped an organization to improve work 
processes, collaboration and work reuse (Majchrzak's, atd 2006). Most respondents reported that wiki and blogs helped them to find relevant information to their work, kept their knowledge updated and made it easier to disseminate their work across organizational boundaries. Individual and group incentives related to time, cost, trust and information quality were found influential in the motivation to use collaboration tools (McAffe, 2006; Wagner, 2004; Glibert et al., 2004, Raman et al., 2005).

Use of Web 2.0 technologies was satisfying for many companies in terms of making cocreation, engaging customers and suppliers in product-development efforts. Based on McKinsey's survey, more than $20 \%$ of respondents used collaboration technologies in internal recruiting, developing product or services, acquiring new customers, tapping network of experts, etc. (McKinsey, 2008).

\section{Factor 4: The link between motivation and making work easier - what does our} data say?

Six out of eight cases from our sample reported that using wikis or blogs helped them with their work in terms of finding relevant information for their day-to-day requirements. Users of wiki web sites found it very helpful to access information and documentation related to their work from one central place. Those users who played an active role in wiki or blog creation received the most satisfaction when finding up-to-date documentation they needed for their own work. In addition, we found that participants 
using wiki web sites for publishing their documents made the transfer of information more efficient. Otherwise, they would have to adopt more conventional transmission, such as sending information to all members, by email.

Finally, we can summarize by stating that using wiki and blogs had positive impacts on user work processes.

Factor 5: The link between motivation and job satisfaction - what does the literature say?

Researchers identified that employees satisfied with their jobs wanted to enhance others respect for their endeavours, improve their professional status and improve their reputation in the company (Majchrzak et al., 2006).

Other research found that trust, information quality, social influence and perceived benefits had significant impact on the intention and willingness to use government web applications (Thong et al., 2000; Belanger and Carter, 2005; Gefen et 1., 2002; Lee et al., 2005; Warkentin et al., 2002; Kumar et al., 2007).

Factor 5: The link between motivation and job satisfaction - what does our data say? 
Our research found that those employees who initiated the blog web applications were satisfied with their job performance. The majority of them were professionals who were motivated to communicate and share their ideas with others and invite others to react to their postings.

Trust played an important role in an organization in terms of participating in a wiki web site. Most wiki web sites had individuals dedicated to creating the content. Other users were invited to participate. The majority of participants were professionals or clients involved in projects. Also it was recorded that smaller groups had better participation in their application than larger group applications.

To conclude, an individual satisfied at his job will have more motivation to participate in Web 2.0 applications. 


\subsection{Factors Prompting Failure}

From the sample of eight government applications using collaboration technology, we obtained a set of 11 factors that were identified as factors with a negative impact on adoption of Web 2.0 technology in government. We will focus only on factors with the most frequent occurrences.

The first five factors with an occurrence greater than $37.5 \%$ (see Table 14) are the most important factors that we need to avoid before and during adoption of new web collaboration tools. They are listed directly below.

- No support from department

- Legal risk / HR risk

- Ownership of information not clear

- Security issues in question

- Data protection in question 
Table 14: Five of the most important failure factors

\begin{tabular}{|l|l|l|l|}
\hline Rank & Occurrences & Factors & Description \\
\hline 1 & $6(75 \%)$ & $\begin{array}{l}\text { No support from } \\
\text { department }\end{array}$ & $\begin{array}{l}\text { Organization does not support } \\
\text { implementation of collaboration tools }\end{array}$ \\
\hline 2 & $5(62.5 \%)$ & Legal risk/HR risk & $\begin{array}{l}\text { Legal risk and HR risk are associated } \\
\text { with the use of Web 2.0 technologies }\end{array}$ \\
\hline 3 & $4(50 \%)$ & $\begin{array}{l}\text { Ownership of } \\
\text { information } \\
\text { published on the } \\
\text { wiki }\end{array}$ & $\begin{array}{l}\text { Who is the owner of published } \\
\text { information on wiki? }\end{array}$ \\
\hline 4 & $3(37.5 \%)$ & $\begin{array}{l}\text { Security issues } \\
\text { Do we need to worry about security } \\
\text { using wiki applications? }\end{array}$ \\
\hline 5 & $3(37.5 \%)$ & Data protection & $\begin{array}{l}\text { How will be data published on } \\
\text { collaborative web sites protected? }\end{array}$ \\
\hline
\end{tabular}

Factor 1: The link between motivation and lack of support from government departments - what does the literature say?

Adoption of Web 2.0 technologies in government is a new emerging area. Despite the fact that the private sector has already considerable experience in using these technologies, government is still far behind in its adoption. Top government management is, however, expected to support implementation and usage of Web 2.0 collaboration tools more significantly in the future (GTEC, 2007). 
Findings from studies related to e-government and innovation in IT revealed that building trust is the underlying catalyst for adoption of new technologies (Warkentin et al., 2002). Other studies were dedicated to the potential willingness to use e-Government in terms of perceived barriers (Gilbert et al., 2004), or lack of skills to use the new technologies (Wargin and Dobiey, 2001). Individuals do not resist the change of and by itself, but rather, they resist loss of status, loss of pay or loss of comfort (Dent and Goldberg, 1999).

According to Caudle's (1991) survey, the top-level public managers are not as keen to implement new changes in IT as are middle-level managers. Similarly, among seven strategies proposed by Gil-Garcia (2005) to overcome integration barriers, one was to obtain executive leadership and legislative support.

There is an understanding that senior managers often deal with unknown issues. At this time, government policies and guidelines have not evolved to include and do not express rules related to the issues created from this new culture of collaboration and knowledge sharing. Our studies included the most important government policies:

- Privacy Act

- Access to Information

- Government Security Policy

- Management of Information Technology Security

- Information and Technology Standards 
Factor 1: The link between motivation and lack of support from departments what does our data say?

Our study indicates that six out of eight cases from the sample felt that their initiatives were not supported by top-level management in their departments. Often the middlelevel managers and IT employees took an initiative to implement collaboration tools, such as wikis and blogs, either for testing purposes or in applications acquired by a client. Our interview recorded that departments either do not yet support Web 2.0 initiatives often found in larger departments, or others left this issue to middle management for resolution. We found that this type of hesitance significantly influenced adoption of Web 2.0. While most IT departments decided to wait for others, some took the initiative and started to build guidelines on how to use new Web 2.0 technologies.

Factor 2: The link between motivation and Legal/HR risk - what does the literature say?

Not being prepared to deal with licence problems, privacy issues and work ethic issues can result in big problems in the legal and human resource area. The literature suggests that human and organizational issues are most critical to the successful development and implementation (Al-Shehry, 2006; Cabrera et al. 2001, Doherty et al., 2003). 
It is good practice in terms of reduction of risk, that web applications with collaboration tools like wikis and blogs, contain a section entitled "The Terms of Use". Terms of use are important because they regulate legal relationships between user and site owners, which later might facilitate dealing with customer complaints (Dilanchian, 2008).

According to Dilanchian (2008), terms of use typically summarize the following legal considerations:

- Definition of who are the parties to the terms of use

- Contract formation (if appropriate) between the owner/operator and the user

- Intellectual property ownership, control and amendment of content - all of which is important for both website and user generated content

- Consent to use of cookies and personal data

- Liability limitation and exclusion for the operator

- Warranties and Indemnity, if any, given by the owner/operator

- Acceptable use rules to apply to all user generated content

- Account suspension rules, termination and consequences of termination

- Governing law and other general or "boiler plate" clauses

Many successful government web sites are experienced with how to consider risk, deal with it and manage it. Mohtashami's work identifies risk for collaborative software development, cites examples of risk management phases and identifies risk principles for collaborative software (Mohtashami et al, 2006). After managing risk, they could exploit 
opportunities offered by Web 2.0. Intellipedia is a good example of this application (Osimo, 2008).

Factor 2: The link between motivation and Legal/HR risk - what does our data say?

Findings from the study revealed that representatives of more than half of the applications were concerned with issues such as copyright problems, legal issues, work ethics issues and human resource issues. We understood that their departments did not yet have established guidelines and policies on collaboration issues when using open Web 2.0 technologies.

We observed that representatives of three internal websites from our sample did not express any legal and/or HR concerns. These web applications built using blogging tools, included a "Disclaimers" section on pages that dealt with the following:

- Compliance with Government Policy: "Effective use of Electronic Networks"

- Ownership of posted blogs and comments

- Departmental guidelines on acceptable content

Finally, we observed that the two blogging applications were updated most regularly and accessed by the most users. 
We can conclude from the above, that the unknown risks from legal, social and work issues have a negative impact on initially using and adopting Web 2.0 technologies.

\section{Factor 3: The link between motivation and ownership of information - what does the literature say?}

It is important to know who the owner is of and who is responsible for shared information over the Web 2.0 application.

Some studies focused on frameworks dealing with complex adoption issues. Scatolini and Cordella (2005) found that organizational climate, decision- making and responsibility assumptions were strong determinants of successful adoption. Janssen and Cresswell (2005) concluded in their studies that a reengineering process and modification assessment of individual responsibilities must be conducted before the implementation and adoption of integrated systems.

\section{Factor 3: The link between motivation and ownership of information - what does our data say?}

Four application representatives from the sample expressed worries about the ownership of published information on the wiki sites. 
Three applications in their disclaimer claimed that the posting belonged to owners and they did not necessarily represent the departmental or branch's position, strategy or opinion.

We observed that the applications with disclaimers stating ownership of information were populated with regular postings, opposed to those applications without any regulations.

We concluded therefore, that a user becomes more motivated to use new collaboration tools if there are clear guidelines and policies from their departments in place.

Factor 4: The link between motivation and security issues - what does the literature say?

The various studies tested different dimensions of perceived risk, such as financial risk, social risk, convenience risk and performance risk (Pires et al., 2004, Miyazaki, 2001). The perceived risk led to security and privacy issues. These issues discouraged people from using government web sites.

While adopting new collaboration technology tools, Government is facing many challenges with this implementation. Some of the difficulties are resistance to change, 
privacy and security and lack of top management support (West, 2004; World Bank, 2003).

Many researchers argue that privacy and security issues remain as barriers to adoption and many such issues must be addressed during implementation (Wilford, 2004; Ndou, 2004).

Factor 4: The link between motivation and security issues - what does our data say?

Although most respondents did not express any problem with security, using wikis and blogs, they were not fully aware of the potential for security breaches, even though their application was the intranet web application used internally.

Our results indicate that there were still 37 percent of respondents who retained some security concerns. To overcome several risks connected with contributions to the web content, web applications had to implement authentication mechanisms and adopt quality assurance policies. Some authors of web applications had it clearly spelled out in their departmental guidelines and policies what was allowed and what was not allowed while using collaboration tools. 
Factor 5: The link between motivation and data protection - what does the literature say?

Reddick's empirical examination of e-government adoption stages resulted in the observation that privacy and security issues limit e-government adoption and growth (Reddick, 2004). Information security and user privacy was always raised in the government environment. Joshi (2001) focused his research on information systems security and assurance. He concluded that confidentiality, integrity, accountability and information assurance are essential management responsibilities. Lambrinoudakis et a1. (2003) created a list of security requirements for entire e-Government activities and included Public Key Infrastructure (PKI) security services (Lofstedt, 2005).

Factor 5: The link between motivation and data protection - what does our data say?

As mentioned, thirty-seven percent of respondents expressed concerns about privacy issues. Respondents worried about data protection published on government internal websites. Health department representatives, for example, reported that data could contain sensitive information. Most applications protected their data by using a formal logging on to the system. We noted that some systems had relatively strong authentication (although not based on PKI credentials) built against one single sign-on infrastructure. The quality of published data was high and controlled by dedicated people. This was visible from the history of changes in wikis. 
On the other hand, some applications, based on volunteer publishing, used weak authentication, only requiring a nickname, password and email address. In most of these cases, the quality of information was lower and was controlled by peer users.

Another observation was that volunteer work was a better motivator to publish data compared to publishing data as a part of the working process.

\section{Identified best practices to support Web 2.0 adoption}

Government leaders implementing Web 2.0 technologies are facing some challenges to implement emerging collaboration technologies. They need to find a solution where the risk is considered and addressed. Based on barrier factors from Table 12, we suggest

implementing some activities and best practices, shown in Table 15, in order to deal with this challenge.

Table 15 shows the resulting best practices identified from the last two sections. The summary of best practices is based on the implementation of success factors, avoidance of negative factors, results from other cases and the literature review. 
Table 15: Suggested best practices

\begin{tabular}{|c|c|c|}
\hline $\begin{array}{l}\text { Activity } \\
\text { type }\end{array}$ & $\begin{array}{l}\text { Related } \\
\text { to } \\
\text { negative } \\
\text { factor } \#\end{array}$ & 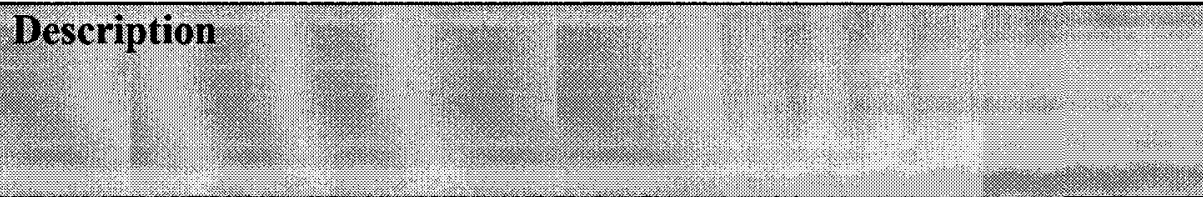 \\
\hline Access & 4,5 & $\begin{array}{l}\text { User should log in before he can view or participate in the discussion. } \\
\text { It provides a measure of security to all users that participants are valid } \\
\text { department employees. }\end{array}$ \\
\hline $\begin{array}{l}\text { Adopt } \\
\text { general } \\
\text { guidelines } \\
\text { and } \\
\text { standards }\end{array}$ & $\begin{array}{l}1,2,3 \\
4,5,11\end{array}$ & $\begin{array}{l}\text { Establish rules for posted information according to: Canadian Charter } \\
\text { of Rights and Freedoms, Privacy Act, Access to Information Policies, } \\
\text { Government Security Policy, Management of Information Technology } \\
\text { Security, Information and Technology Standards }\end{array}$ \\
\hline $\begin{array}{l}\text { Develop } \\
\text { organization } \\
\text { policies }\end{array}$ & $\begin{array}{l}1,2,3 \\
4,5\end{array}$ & $\begin{array}{l}\text { Develop appropriate policies and align them with strategic } \\
\text { information policy } \\
\text { Address legal issues and HR issues } \\
\text { Address privacy and security issues } \\
\text { Monitor, analyze and change policies when appropriate } \\
\text { Make sure that everyone in the department understand these policies }\end{array}$ \\
\hline $\begin{array}{l}\text { Create value } \\
\text { for the } \\
\text { organization }\end{array}$ & $1,9,10$ & Determine the impact of blogs and wikis on organization processes \\
\hline $\begin{array}{l}\text { Monitoring } \\
\text { Usage }\end{array}$ & $\begin{array}{l}6,8,9 \\
10\end{array}$ & $\begin{array}{l}\text { Measuring usage and participation by number of log files } \\
\text { Monitoring compliance with policy and context of blogs }\end{array}$ \\
\hline $\begin{array}{l}\text { Measuring } \\
\text { Usefulness }\end{array}$ & 10,11 & $\begin{array}{l}\text { Measuring the usefulness of your blog, if they met the purpose } \\
\text { Compare value of blogs and other collaboration software } \\
\text { Determine cost and time spent on producing blogs and wikis. }\end{array}$ \\
\hline $\begin{array}{l}\text { Create } \\
\text { useful rules } \\
\text { and good } \\
\text { practices to } \\
\text { write blogs } \\
\text { and wikis }\end{array}$ & $\begin{array}{l}7,8,10 \\
11\end{array}$ & $\begin{array}{l}\text { Increasing the productivity of your employees by improving "in- } \\
\text { house" culture } \\
\text { Organize meetings to brainstorm about advantages and risks of using } \\
\text { blogs and wikis } \\
\text { Make sure everyone understands policies on blogs and wikis } \\
\text { Make consequences of misuse clear, change policies }\end{array}$ \\
\hline
\end{tabular}




\subsection{Propositions}

Figure 4 identifies a model representing the summary of our research. The model is anchored around motivational factors that affect a successful adoption of Web 2.0 technologies in the Canadian government.

Figure 4: Model representing motivational factors that affect adoption of Web 2.0

\section{Motivational Factors:}

- Knowledge sharing

- Knowledge creation

- Communication enhancement

- Making work easier

- Job satisfaction

\section{Organizational Factors:}

- Lacking top management support

- Legal and HR risk

- Departmental policies, guidelines and standards

- Implementing actions and best practices

The following propositions were formed and concluded:

\section{Motivational Factors}

Proposition 1: The need for knowledge sharing is positively related to the employees' intention to use Web 2.0 collaboration tools. 
Proposition 2: The need to create an expert knowledge is positively related to the employees' intention to use Web 2.0 technologies.

Proposition 3: The extent of communication encouragement and enhancement is positively related to the employees' intention to use Web 2.0 technologies.

Proposition 4: The extent to which collaboration tools are making work easier is positively related to the employees' intention to use Web 2.0 collaboration tools.

Proposition 5: The extent to which the employees were satisfied with their jobs is positively related to the employees' intention to use Web 2.0 collaboration tools.

\section{Organizational Factors}

Proposition 6: The lack of support from top management is negatively related to the employees' intention to use Web 2.0 collaboration tools.

Proposition 7: The legal and HR risk associated with using a shared workspace is negatively related to the employees' intention to use Web 2.0 collaboration tools.

Proposition 8: The lack of departmental policies, guidelines and standards dealing with privacy, security and ownership issues, which are related to shared information 
workspace, is negatively related to the employees' intention to use Web 2.0 collaboration tools.

Proposition 9: The extent to which proposed action and best practices are implemented within the working department is positively related to the employees' intention to use Web 2.0 collaboration tools. 


\section{CONCLUSIONS, LIMITATIONS AND SUGGESTIONS FOR FUTURE RESEARCH}

The chapter is organized into three sections. The first section provides the conclusion. The second section identifies the limitations of this study. Finally, the last section offers suggestions for future research related to adoption of Web 2.0 technologies in the government.

\subsection{Conclusions}

The objective of this research was to examine why the implementation of new Web 2.0 technologies is not happening faster in Canadian Government Departments. The research was done in two Phases. In Phase I, we identified a research sample of eight web applications as early adopters of new collaboration tools, and gathered a preliminary list of possible problems and excuses about implementation of new web technologies. In Phase II, we identified motivational factors for successful adoption, identified possible problems with implementation of Web 2.0 , and attempted to identify ways to prevent these problems. This research answers three questions: 
1. What are the factors that drive adoption of Web 2.0 technologies?

2. What are the issues that make adoption challenging?

3. What are the best practices for adoption of new technologies in the government?

Based on our results from early adopters, we can conclude that the adoption of Web 2.0 technologies is linked to:

- Motivational factors based on individual response to usage of new technology is the most dominant factor for adoption

- Organizational factors based on department behaviour as a response to changes will help with adoption

In particular:

- According to our observations, top managers are discouraged with negative aspects of adoption and wait for others to deal with these issues

- Privacy and security were identified as factors that were not dominant for the successful adoption of Web 2.0 technologies

The results of this study suggest that individuals' motivation affects usage of new collaboration tools. Five propositions related to motivational behaviour were offered in Section 5.3. The intention to use Web 2.0 technology was driven by the extent to which 
users wanted to share or create knowledge, be part of an enhanced communication framework, make their work easier or the degree of satisfaction with their job.

The results of this study also suggest that organizational response to changes caused by Web 2.0 technologies affects their adoption. Four propositions related to organizational factors were offered in Section 5.3. Successful adoption of Web 2.0 technologies in government departments was related to top management support and a perceived policy vacuum in administrative issues, such as legal and HR risk, departmental policies, guidelines and standards, and best practices related to implementation.

To overcome a fear of the unknown and to take advantage of new technologies, while at the same time avoiding risk, the research suggested seven supporting actions and best practices (see Table 15) that government departments and agencies should adopt and implement in the workplace.

\subsection{Limitations}

This research has three main limitations. 
The first limitation is that the research studied only internal government web sites. Due to the lack of public government web sites using Web 2.0 technologies, the sample did not cover Internet web sites open to the public.

The second limitation is that the sample could not include the use of different type of Web 2.0 technologies, namely using social networks, because of the current ban in some departments.

The last limitation is that during the study period, some government web sites in the sample had only recently been created, and therefore still had low participation rates, inadequate for comprehensive review.

\subsection{Suggestions for Future Research}

First, the results from this study used qualitative data extrapolated from interviews. While qualitative research is appropriate for the study of a new phenomenon, future research should be based on a quantitative approach to data analysis.

The second suggestion would be to examine the success of Web 2.0 implementation, as it evolves, in public web sites after the policy vacuum is removed. 
The third suggestion would be to understand the differences between using collaboration tools in personal life and in an organizational setting. Why does it seem that people are more comfortable to use these tools in their homes?

The last suggestion for future research is to examine potential use of social networking sites, such as Facebook, Flickr, YouTube, Amazon, GoogleTalk, and Second Life, by the Government of Canada in terms of benefits these sites may offer for the positive evolution of IT communications for the Government of Canada. 


\section{REFERENCES}

$\mathrm{AAFC}, 2008$. New technologies and $\mathrm{CG}$ communication. Research for project $P O R$ 130-07 and POR 300-07. Retrieved on Aug 28, 2008 from

$\underline{\text { www.porr-rrop.gc.ca }}$

AL-Shehry, A., Rogerson, S., Fairweather, N.B. and Prior, M., 2006. The motivation for change toward e-government adoption: Case studies from Saudi Arabia. eGovernment Workshop '06. Brunel University, West London

Anderson, C. 2006. The Long Tail: How Endless Choice is Creating Unlimited Demand. London: Random House.

Burt, R. 1992. Structural Holes: The Social Structure of Competition. Harvard University Press, Cambridge, MA.

Cabrera, A., Elizabeth, F. and Barajas, C. 2001. 'The key role of organisational culture in a multi- system view of technology- driven change'. International Journal of Information Management. 21: 245-261.

Carter, L. and Bélanger, F. 2005. "The Utilization of e-government services: citizen trust, innovation and acceptance." Information Systems Journal. 15(1): 5-25. 
Caudle, S.L., Gorr, W.L. and Newcome, K.E. 1991 "Key Information Systems Management Issues for the Public Sector." MIS Quarterly.15(2):171-188.

Citizens First, 1998. Erin Research Inc. for Citizen Centred Service Network. Ottawa: Canadian Centre for Management Development.

Chadwick, A., 2008. Web 2.0: New challenges for the study of e-democracy in an era of information exuberance. A Journal of Law and Policy for the Information Society. 4(3).

Chircu, A.M. and Lee, D. H. 2003. "Understanding IT Investments in the Public Sector: The Case of E-Government," Ninth Americas Conference on Information System., 792-800.

Clark, H. 1996. Using Language. Cambridge University Press, New York

Clockwork, 2004-last update. A framework of e-governance and ICT best practices. Homepage of International institute for communication and development. Retrieved on Jun 10, 2008 from http://www.iicd.org/about 
Cramton, C.D. 2001.The mutual knowledge problem and its consequences for dispersed collaboration. Organ. Sci. 12(3): 346-371.

Dilanchian, N. 2008. Dilanchian lawyer \& consultant: Website terms of use reduce risk. Retrieved on Jun 10, 2008 from http://www.dilanchian.com.au/ip-tech-e-biz/website-terms-of-use-reducerisk.html

Directions Magazine. 2006. Gartner's 2006 Emerging Technologies Hype Cycle Highlights Key Technology Themes.

Desmarais, M. \& Kennedy, S., 2003. 'Award-winning Contact CentresDemonstrating that Employee Satisfaction Drives Customer Satisfaction,' Contact Management Publication. Retrieved on May 10, 2008 from http://sqmgroup.com/awardwin.html

Dent, E. B. and Goldberg, S. G.1999. Challenging "Resistance to Change" Dent and Goldberg. Journal of Applied Behavioural Science. 35: 25-41.

Doherty, N., King, M. and Al-Mushayt, O. 2003. The impact of inadequacies in the treatment of organizational issues on information systems development projects. Information \&Management, 41(1): 49-62. 
Ebrahim, Z.,Irani, Z. and Alshawi, S. 2004. A strategic framework for e-government adoption in public sector. American conference on Information systems, New York, USA. $6^{\text {th }}-8^{\text {th }}$ August.

Eisenhardt, K. M. 1989. "Building theories from case study research". Academy of Management Review. 16(3): 620-627.

Egger, B. \& Goldsmith, S., 2004. Governing by Network: The New Shape of the Public Sector. Brookings Institution Press.

EKOS Research, 2002. The Dual Digital Divide IV. Ottawa: Ekos Research Associates Inc.

Espiner, T. 2006. Industry Watch Toolkit: "How will emerging tech affect your company?" CNET Networks. Retrieved on Jun 122, 2008 from http://news.zdnet.co.uk/itmanagement $/ 0,1000000308,39280643,00$ html

Fornell, C., 2002. ACSI Commentary: "Federal Government Scores". Retrieved on Dec 16,2007 from http://www.theacsi.org/government/govt-02c.html 
Fuchs-Kittowski, F. and Kohler, A., 2005. Wiki communities in the context of work processes. International Symposium on Wikis Proceedings of the 2005 international symposium on Wikis San Diego, California. pp: $33-39$.

Galbraith, J.R.1973. Designing Complex Organizations. Reading, MA, AddisonWesley.

Gakunu, P., 2004-last update, E-Government Strategy for Kenya. Retrieved on Jun 10, 2008 from

http://www.apc.org/apps/img upload/6972616672696361646f63756d656e74/ego

Gartner, 2007. Web 2.0 in government: Blessing or curse? Retrieved on Jun 21, 2008 from

http://www.gartner.com/DisplayDocument?id=554683

Gefen, D., Pavlou, M., Warkentin and Gregory, M.R. 2002. "E-government Adoption," Proceedings of the Eighth Americas Conference on Information Systems.

Gichoya D., 2005. "Factors Affecting the Successful Implementation of ICT Projects in Government" The Electronic Journal of e-Government . 4(3): 175-184.

Gil-Garcia, J.R., Schneider, C.A., Pardo, T.A. and Creswell, A.M. 2005. 
"Interorganizational Information Integration in the Criminal Justice Enterprise:

Preliminary Lessons from State and County Initiatives," Proceedings of the 38th Hawaii International Conference on System Sciences.

Gil-Garcia, J. R., Pardo, T. P. and Baker, A. 2007. Understanding Context through a Comprehensive Prototyping Experience: A Tested Research Strategy for Emerging Technologies. Proceedings of the 40th Hawaii International Conference on System Sciences. Center for Technology in Government, University at Albany, SUN Glibert, D. and Balestrini P. 2004. Barriers and benefits in the adoption of egovernment.

The International Journal of Public Sector Management. 17 (4).

GTEC, 2007. IT Governance overview. Retrieved on Jun 10, 2008 from http:/www.tbs-sct.gc.ca/cio-dpi/pres/2007/overv-aperc/page01-eng.asp

Hansen, M. 2002. Knowledge networks: Explaining effective knowledge sharing in multiunit companies." Organization Science 13(3): 232-248.

Heintzman, R., and Marson, B., 2003. The search for a service-value chain within the Canadian public sector. Paper presented at the EGPA annual conference, Oeiras, Portugal, Study Group II. 
Hernon, P., 1998. Government on the Web: A Comparison between the United States and New Zealand, Government Information Quarterly. 15(4): 419-443.

Heskett, J. L., Earl S., W. Jr. and Schlesinger, L. A., 1997. The Service Profit Chain: How Leading Companies Link Profit and Growth to Loyalty, Satisfaction, and Value. New York: The Free Press.

Hewitt, 2003. "What Does It Take to Be a Best Employer?", presentation to Treasury Board of Canada Secretariat Executive Committee.

Ifinedo, P., 2005. Measuring Africa 's e-Readiness in the global networked economy: A nine-country data analysis. Retrieved on Jun 10, 2008 from http://ijedict.dec.uwi.edu/viewarticle.php?id=12\&layout=html

Janssen, M., and Cresswell, A. 2005. The Development of a Reference Architecture for Local Government. Proceedings of the 38th Hawaii International Conference on System Sciences

Karahanna, E., Straub, D., Chervany, N.1999. Information Technology Adoption 'Across Time: A Cross-Sectional Comparison of Pre-Adoption and Post-Adoption Beliefs. MIS Quarterly. 23(2):183-213. 
Kawalek, P. and Wastall, D. 2005. "Pursuing Radical Transformation in Information Age

Government: Case Studies Using the Sprint Methodology." Journal of Global Information Management, 13(1):79-101.

Khaled, M., 2003-last update. Information technology in government: an action plan for Bangladesh. Retrieved on Jun 10, 2008 from http://www.sictgov.org/IT\%20Action\%20Plan\%20for\%20BG.doc

Kumar V, Mukerji B, Butt I and Persaud A. 2007. Factors for Successful e-Government Adoption: a Conceptual Framework. The Electronic Journal of e-Government. 5(1): 63 -76 .

Lam, A. 1997. Embedded firms, Embedded knowledge: Problems of collaboration and knowledge transfer in global cooperative ventures. Organization Studies. 18(6): 973996.

Lambrinoudakis, C., Gritzalis, S., Dridi, F., and Pernul, G. 2003. Security requirements for e-government services: A methodological approach for developing a common PKIbased security policy. Computer Communications. 26(16): 1873-1883. 
Layne, K. and Lee, J. 2001. "Developing fully functional E-government: A four stage Model." Government Information Quarterly. 18: 122-136.

Lee, J.K., Kim, D.J. and Rao, H.R. 2005. An Examination of Trust Effects and Preexisting Relational Risks in e-Government Services. Proceedings of the Eleventh Americas Conference on Information Systems. Omaha, NE. USA.

Lofstedt, U. 2005. E-Government: Assessment of current research and some proposals for future direction. International Joumal of Public Information Systems. 2005(1).

Majchrzak, A., Wagner, C., and Yates, D. 2006. Corporate Wiki Users. Results of a Survey. 99-104. San Diego: ACM Press.

Marschak, J. and R. Radner. 1972. Economic Theory of Teams. Yale University Press, New Haven, CT.

McAfee, A. P. 2006. Enterprise 2.0: The dawn of emergent collaboration. MIT Sloan Management Review, 47 (3): 21-28.

McKinsey, 2008. McKensey Global Survey Result: Building the Web 2.0 enterprise. The McKinseay Quarterly. July 2008. 
Michiak, A. and Desmarais, M., 2000. 'Traits that Create Satisfaction', Canadian Call Centre News. Supplement. March.

Miyazaki, A. D. and Fernandez, A. 2001. "Consumer Perceptions of Privacy and Security Risks for Online Shopping". Journal of Consumer Affairs, 35(1): 27-44.

Mohtashami, M., Marlowe, T., Kirova, V. and Deek. F. P. 2006. Risk Management for Collaborative Software Development. www.ism-journal.com. Fall 2006.

Moir, P. 2006. IM Conference 2006: Leveraging Web 2.0 in the Government of Canada. NRC. Retrieved on Nov 10, 2007 from http://www.tbs-sct.gc.ca/im-gi/imday06jourgi/info/moir/page01 e.asp

Moon, M.J. and S. Bretschneider, 2002. "Does the Perception of Red Tape Constrain IT Innovation in Organizations? Unexpected Results from Simultaneous Equation Model and Implications," Journal of Public Administration Research and Theory, 12(2): 273-291.

Moran, C.R.1998. Strategic information technology planning in higher education: A new roadmap to the 21 st century academy. 1 edn. Bolton, MA: Anker Publishing Company, Inc. 
MORI Social Research Institute, 2003. 'Exploring Trust in Public Institutions - New Findings: National Quantitative Survey. Report for the Audit Commission'. Retrieved on Jun 10,2007 from

http://www.audit-commission.gov.uk/Products/AC-REPORT/B0767D2A-F8C2- 4D4BA925-34AAE914A6C4/TrustinPublicInstitutionsnewfindingsMORI.pdf

Mugonyi, D.2003. US queries new computer deal. Homepage of Nation Media Group. Retrieved on May 10, 2007 from:

http:/www.nationaudio.com/News/DailyNation/03092003/News/News81.html

Ndou, V, 2004. E-Government for developing countries: Opportunities and challenges.

Retrieved on Jan 10, 2007 from

http://www.is.cityu.edu.hk/research/ejisdc/vol18/v18r1.pdf

Oakley, J. 2005. Linking Organizational Characteristics to Employee Attitudes and Behaviour: A Look at the Downstream Effects on Market Response and Financial Performance. Northwestern University: Forum for People Performance Management and Measurement. 
O'Reilly, T. 2005. What Is Web 2.0: Design Patterns and Business Models for the Next Generation of Software. O'Reilly. Retrieved on Jun 10,2008 from http:/www.oreillynet.com/pub/a/oreilly/tim/news/2005/09/30/what-is-web-20.html

Osimo, D. 2008. Web 2.0 in government: why and how? Technical Report. JRC, EUR 23358.

Pires, G., Stanton, J., and Eckford, A. 2004. "Influences on the perceived risk of purchasing online". Journal of Consumer Behaviour. 4(2):118-131.

Raman, M., Ryan, T., and Olfman, L. 2005. Designing knowledge management systems for teaching and learning with wiki technology. Journal of Information Systems Education. 16(3): 311-320.

Reddick, C. 2004. Empirical Models of E-Government Growth in Local Governments. E-Service Journal. 3:2.

Richard, L. 2006. Web 2.0 Trends and Technologies: Example of a NRCan-ESS project Blog. NRC. Retrieved on Nov 10, 2007 from http://www.tbs-sct.gc.ca/im-gi/imday06jourgi/info/richard/page01 e.asp

Riley, T.B. 2000. Electronic governance and electronic democracy: Living and working in the wired world. London: Commonwealth Secretariat. 
Rogers, E.M. 1995. "Diffusion of innovations". New York, NY: Free Press.

Scatolini, E. and Cordella, A. 2005. "Technological artifacts and sense making in an Italian Public Administration," 21st European Group for Organisational Studies (EGOS) Colloquium, Berlin.

Schildt, K., Beaumaster, S. and Edwards, M. 2005. "Strategic Information Technology Management: Managing Organizational, Political, and Technological Forces". Proceedings of the 38th Hawaii International Conference on System Sciences.

Schmidt, F. 2004. "Identifying the Drivers of Staff Satisfaction and Commitment in the Public Sector", paper prepared for the Public Service Human Resources Management Agency of Canada. Schmidt and Carbol Consulting Group.

Simon, H. 1991. "Bounded Rationality \& Organizational learning." Organization Science. (2:1):125-134.

SQM, 2005. "Employee and Customer Relationship Study", presentation prepared for the Treasury Board of Canada Secretariat. 
Spence W .1994.' Innovation: The Communication of Change in Ideas, Practices and Products'. Champn and Hall, London,UK.

Tan, C.W., S.L, Pan and E.T.K. Lim. 2005. "Towards the Restoration of Public Trust in Electronic Governments: A Case Study of the E-Filing System in Singapore," Proceedings of the 38th Hawaii International Conference on System Sciences.

Titah, R., and Barki, B. 2006. "E-government adoption and acceptance: a literature review". International Journal of Electronic Government Research, 2(3): 23-57.

Thong, J.Y.L., C.S. Yap and K.L. Seah. 2000. "Business Process Reeingineering in the Public Sector: The case of the Housing Development Board in Singapore," Journal of Management Information Systems, 17(1): 245-270.

Van de Walle, S. 2004. Perceptions of Administrative Performance: The Key to Trust in Government? Leuven: Instituut voor de Overheid, Departement Politieke Wetenschappen, Faculteit Sociale Wetenschappen, Katholike Universiteit Leuven.

Ventura, S.J. 1995. "The Use of Geographic Information Systems in Local Government, "Public Administration Review, 55(5): 461-467. 
Vieira, S. 2002. The Key Drivers of Job Satisfaction in the Manitoba Public Service. Service Manitoba.

Wagner, C. 2004. Wiki: A Technology for Conversational Knowledge Management and Group Collaboration. Communications of the Association for Information Systems. (13): 265-289.

Wargin, J., Dobiéy, D. 2001, "E-business and change: Managing the change in the digital economy", Journal of Change Management, 2(1):.72-82.

Warkentin, M.., Gefen, D., Pavlou, P.A. and Rose, G.M. 2002. "Encouraging Citizen Adoption of e-Government by Building Trust," Electronic Markets. 12(3):157-162.

Welch, E.W. and S. Pandey, 2005. "E-Government and Network Technologies: Does Bureaucratic Red Tape Inhibit, Promote or Fall Victim to Intranet Technology Implementation?" Proceedings of the 38th Hawaii International Conference on System Sciences.

West, D.M.2004. "E-Government and the transformation of service delivery and citizen attitudes". Public Administration Review 64 (1): 15-27. 
Wilford S. 2004. "E-government: Participation or Panopticon". University of the Aegean. ETHICOMP 2004, Volume 2: 927.

World Bank. 2003. "A Definition of E-Government". Retrieved on Jan 8, 2007 from www.worldbank.org/publicsector/egov/definition.htm

Yin R. 2003. Case study research: design and methods. California. USA. Sage Publications. Thousand Oaks.

Zikmund, W. G. 1994. Exploring Marketing Research. Florida: Dryden Press. 


\section{APPENDIX}

Table 16: E-government adoption and acceptance: organizational benefits (adapted from: Titah and Barki, 2005)

\begin{tabular}{|c|c|c|c|c|}
\hline Aw1m, & 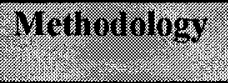 & 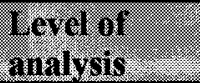 & 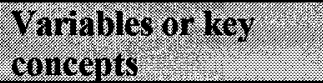 & 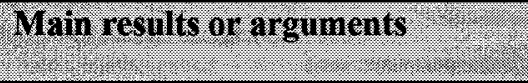 \\
\hline $\begin{array}{l}\text { Gi-Garcia et } \\
\text { al. } \\
(2005)\end{array}$ & $\begin{array}{l}\text { Literature review } \\
\text { Case sfudy } \\
\text { (secondary data) } \\
\mathrm{N}=3\end{array}$ & Organizational & $\begin{array}{l}\text { Barriers to integration } \\
\text { Turf and resistance } \\
\text { IT and Data } \\
\text { incompatibility } \\
\text { Organizational } \\
\text { diversity } \\
\text { Environmental and } \\
\text { Institutional } \\
\text { complexity }\end{array}$ & $\begin{array}{l}\text { Proposes } 7 \text { strategies to overcome } \\
\text { Integration barriers: } \\
\text { - retain autonomy of the involved agencies } \\
\text { establish and exercise a governance } \\
\text { structure } \\
\text { - secure strategic partnerships } \\
\text { - build on long-range and comprehensive } \\
\text { planning } \\
\text { - build understanding of the business process } \\
\text { - secure adequate financial resources } \\
\text { - obtain and nurture executive leadership and } \\
\text { legislative support }\end{array}$ \\
\hline $\begin{array}{l}\text { Lee et al. } \\
(2005)\end{array}$ & $\begin{array}{l}\text { Field survey } \\
\mathrm{N}=84\end{array}$ & Individual & $\begin{array}{l}\text { E-file experience } \\
\text { Perceived potential } \\
\text { benefit } \\
\text { Trust in eGovernment } \\
\text { Belief in Goodwill } \\
\text { Domain competence } \\
\text { Internet competence } \\
\text { Trust in Government and } \\
\text { Businesses } \\
\text { Disposition to trust } \\
\text { Internet risk } \\
\text { Internet self-efficacy } \\
\text { Intention to use }\end{array}$ & $\begin{array}{l}\text { Belief in IRS Goodwill did not have a } \\
\text { significant direct or } \\
\text { indirect effect on intention to use. } \\
\text { Internet competence belief was found to } \\
\text { have a } \\
\text { significant indirect effect, through potential } \\
\text { benefit, on } \\
\text { intention to use. } \\
\text { The interaction of relational risk and goodwill } \\
\text { of third } \\
\text { party was found to be a "possible determinant" } \\
\text { of } \\
\text { intention to use. } \\
\text { Trust in Government was found to influence } \\
\text { the belief in } \\
\text { the goodwill of e-Government authority. } \\
\text { Direct positive experience was found to have } \\
\text { a significant } \\
\text { effect on trusting beliefs. }\end{array}$ \\
\hline $\begin{array}{l}\text { Norris and } \\
\text { Moon } \\
(2005)\end{array}$ & $\begin{array}{l}\text { Ffeld survey } \\
\mathrm{N}=1881 \text { local } \\
\text { governments in } \\
2000 \text {, and } \mathrm{N}= \\
4125 \text { local } \\
\text { governments in } \\
2002 \text {. }\end{array}$ & Organizational & $\begin{array}{l}\text { Adoption } \\
\text { Organizational } \\
\text { characteristics } \\
\text { Organizational output and } \\
\text { outcomes }\end{array}$ & $\begin{array}{l}\text { Local governments in the US "continue to } \\
\text { make } \\
\text { incremental progress in adopting and } \\
\text { deploying egovernment } \\
\text { systems" ( } p .72 \text { ). } \\
\text { Adoption of web sites by public } \\
\text { administrations "is } \\
\text { strongly related to local government size } \\
\text { (measured in } \\
\text { terms of population)" ( } p .72 \text { ) } \\
\text { "Not all reported impacts of e-government } \\
\text { are positive" } \\
\text { (p. } 72 \text { ). } \\
\text { The most significant barriers to e- } \\
\text { government adoption } \\
\text { include lack of technology, web staff, and } \\
\text { financial } \\
\text { resources, as well as privacy and security } \\
\text { issues. }\end{array}$ \\
\hline $\begin{array}{l}\text { Scatolini and } \\
\text { Cordella (2005) }\end{array}$ & $\begin{array}{l}\text { Action research } \\
\mathrm{N}=1 \text { project }\end{array}$ & Organizational & $\begin{array}{l}\text { IT adoption: } \\
\text { IT sensemaking } \\
\text { IT as a social object }\end{array}$ & $\begin{array}{l}\text { "Management capacity of the direction," } \\
\text { personal and } \\
\text { professional training" and "sharing } \\
\text { responsibility for } \\
\text { change" were found to be the most significant } \\
\text { issues } \\
\text { affecting IT implementation and adoption. } \\
\text { The "defence of political bonds" was found to } \\
\text { be the most salient resistance factor to IT } \\
\text { adoption. }\end{array}$ \\
\hline
\end{tabular}




\section{Table 17: E-government adoption and acceptance: knowledge sharing (adapted from: Titah and Barki, 2005)}

\begin{tabular}{|c|c|c|c|c|}
\hline Authors & Methollology & $\begin{array}{l}\text { Level of } \\
\text { amatris }\end{array}$ & $\begin{array}{l}\text { Varinhles or key } \\
\text { concents }\end{array}$ & Mam resulis or arguments \\
\hline $\begin{array}{l}\text { Carter and } \\
\text { Bëlanger } \\
(2005)\end{array}$ & $\begin{array}{l}\text { Field survey } \\
\mathrm{N}=105\end{array}$ & Individual & $\begin{array}{l}\text { Compatibility } \\
\text { Relative advantage } \\
\text { Image } \\
\text { Complexity } \\
\text { PEOU } \\
\text { PU } \\
\text { Trust of Internet } \\
\text { Trust of Government } \\
\text { Intention to use }\end{array}$ & $\begin{array}{l}\text { Compatibility, PEOU, and Perceived: } \\
\text { trustworthiness } \\
\text { were found to significantly influence } \\
\text { citizens' intention to } \\
\text { use. } \\
\text { Image and Relative advantage did not } \\
\text { have a significant } \\
\text { influence on intention to use. }\end{array}$ \\
\hline $\begin{array}{l}\text { Lee, Braynov } \\
\text { and } \\
\text { Rao (2005) }\end{array}$ & $\begin{array}{l}\text { Field survey } \\
N=158\end{array}$ & Individual & $\begin{array}{l}\text { Trust in the Government } \\
\text { Perceived public } \\
\text { emergency } \\
\text { Trusting beliefs in e- } \\
\text { Government } \\
\text { Perceived riskiness } \\
\text { PU } \\
\text { Intention to depend on } \\
\text { information } \\
\text { Intention to provide } \\
\text { personal } \\
\text { information } \\
\text { Intention to use }\end{array}$ & $\begin{array}{l}\text { Citizens' trust in the Government and } \\
\text { Perceived public } \\
\text { scrutiny were found to have marginal } \\
\text { effects on individual } \\
\text { Trusting beliefs in e-Government, } \\
\text { Perceived riskiness of } \\
\text { the Internet, and Perceived usefulness of } \\
\text { e-Government } \\
\text { services. } \\
\text { Trusting beliefs in e-Government and } \\
\text { PU had a } \\
\text { significant effect on Intention to use, on } \\
\text { Intention to } \\
\text { provide personal information, and on } \\
\text { Intention to depend } \\
\text { on information. } \\
\text { Perceived riskiness had a significant } \\
\text { and negative effect } \\
\text { on Intention to }\end{array}$ \\
\hline $\begin{array}{l}\text { Wang et al. } \\
(2005)\end{array}$ & $\begin{array}{l}\text { Case study } N=1 \\
\text { Lab experiment } \\
N=1\end{array}$ & Individual & $\begin{array}{l}\text { Task characteristics } \\
\text { Process outcome } \\
\text { Site characteristics } \\
\text { Individual characteristics }\end{array}$ & $\begin{array}{l}\text { Develops a client centric Web design } \\
\text { methodology. }\end{array}$ \\
\hline
\end{tabular}


Table 18: E-government adoption and acceptance: knowledge creation (adapted from: Titah and Barki, 2005)

\begin{tabular}{|c|c|c|c|c|}
\hline Author: & Methoilology & $\begin{array}{l}\text { Tevel of } \\
\text { malyols }\end{array}$ & $\begin{array}{l}\text { Variables or key. } \\
\text { concepts }\end{array}$ & Wain results or arguments. \\
\hline $\begin{array}{l}\text { Gilbert et al. } \\
(2004)\end{array}$ & $\begin{array}{l}\text { Field survey } \\
\mathrm{N}=111\end{array}$ & Individual & $\begin{array}{l}\text { Perceived relative } \\
\text { benefits } \\
\text { Avoid personal interaction } \\
\text { Cost } \\
\text { Time } \\
\text { Perceived barriers } \\
\text { Visual appeal } \\
\text { Experience } \\
\text { Financial security } \\
\text { Information quality } \\
\text { Low stress } \\
\text { Trust: } \\
\text { Willingness to use }\end{array}$ & $\begin{array}{l}\text { Time, Cost, Financial security, Trust and } \\
\text { Information } \\
\text { quality were found to significantly influence } \\
\text { willingness to } \\
\text { use. } \\
\text { Ease of use was not found to be a } \\
\text { significant determinant } \\
\text { of willingness to use. } \\
\text { Older respondents ( } 55+\text { ) were found to } \\
\text { be less willing to } \\
\text { use online public services than younger } \\
\text { ones. }\end{array}$ \\
\hline Moon (2002) & $\begin{array}{l}\text { Survey } \\
N=1471\end{array}$ & Organizational & $\begin{array}{l}\text { E-government adoption } \\
\text { E-government evolution } \\
\text { Information stage } \\
\text { Two-way communication } \\
\text { stage } \\
\text { Service and financial } \\
\text { transaction } \\
\text { Vertical and horizontal } \\
\text { integration } \\
\text { Political participation }\end{array}$ & $\begin{array}{l}85.3 \% \text { of the responding municipal } \\
\text { governments had a } \\
\text { Website, and } 57.4 \% \text { of them had an } \\
\text { intranet: } \\
8.2 \% \text { of the responding municipal } \\
\text { governments were found } \\
\text { to have a "comprehensive strategy or } \\
\text { master plan to guide } \\
\text { their future e-government initiatives," } \\
\text { Adoption and longevity of municipal } \\
\text { government Websites } \\
\text { were found to be positively associated with } \\
\text { their size. } \\
\text { Lack of financial resources, lack of } \\
\text { technology staff and } \\
\text { expertise, technological upgrades, security } \\
\text { and privacy } \\
\text { issues were found to hinder e-government } \\
\text { adoption and } \\
\text { evolution. }\end{array}$ \\
\hline
\end{tabular}


Table 19: E-government adoption and acceptance: enhanced employee participation (adapted from: Titah and Barki, 2005)

\begin{tabular}{|c|c|c|c|c|}
\hline Anthors: & Methoilowgry & $\begin{array}{l}\text { Level of } \\
\text { anavsis: }\end{array}$ & $\begin{array}{l}\text { Variables or liey } \\
\text { concepts }\end{array}$ & Main results or arguments \\
\hline $\begin{array}{l}\text { Thong et al. } \\
(2000)\end{array}$ & $\begin{array}{l}\text { Case study } \\
N=1\end{array}$ & Project & $\begin{array}{l}\text { Radical change } \\
\text { Change methodology } \\
\text { Differences between } \\
\text { public and private sector }\end{array}$ & $\begin{array}{l}\text { Public organizations are "highly resistant } \\
\text { to change" ( } \mathrm{p} \text {. } \\
265 \text { ). } \\
\text { Mass-media communication plays an } \\
\text { important role in } \\
\text { informing public managers about the } \\
\text { necessity of } \\
\text { change as well as its challenges. } \\
\text { A neutral reengineering team facilitates } \\
\text { the change } \\
\text { process. } \\
\text { Management support facilitates the } \\
\text { implementation } \\
\text { process } \\
\text { The use of pilot sites is an important } \\
\text { success factor for } \\
\text { o-government adoption. }\end{array}$ \\
\hline $\begin{array}{l}\text { Gefen et al. } \\
(2002)\end{array}$ & $\begin{array}{l}\text { Field survey } \\
N=243 \mathrm{MBA} \\
\text { students }\end{array}$ & Individual & $\begin{array}{l}\text { PU } \\
\text { PEOU } \\
\text { Social influence } \\
\text { Perceived risk } \\
\text { Belief in Humanity } \\
\text { Disposition to trust } \\
\text { Predictability } \\
\text { integrity } \\
\text { Benevolence } \\
\text { Ability } \\
\text { Intention to use } \\
\text { Perceived social } \\
\text { characteristics } \\
\text { Institutional guarantees } \\
\text { Process-mode trust } \\
\text { Nature of expected } \\
\text { interaction }\end{array}$ & $\begin{array}{l}\text { PU and Social influence had a } \\
\text { significant impact on } \\
\text { intention to use and explained } 33 \% \text { of its } \\
\text { variance. } \\
\text { PEOU had a significant impact on PU. } \\
\text { Social inffuence and Trust were found to } \\
\text { have a } \\
\text { significant impact on PU. } \\
\text { Perceived risk had a significant and } \\
\text { negative impact on } \\
\text { PU. } \\
\text { Trust had a significant and negative } \\
\text { impact on Risk. } \\
\text { Trust had a significant influence on } \\
\text { PEOU. } \\
\text { Trust was found to be significantly } \\
\text { influenced by Belief in } \\
\text { Humanity, the Nature of expected } \\
\text { interaction, the } \\
\text { Perceived social characteristics, and by } \\
\text { the Institutional } \\
\text { guarantees. } \\
\text { Disposition to trust had no influence on } \\
\text { Trust. }\end{array}$ \\
\hline $\begin{array}{l}\text { Coursey et al. } \\
(2005)\end{array}$ & $\begin{array}{l}\text { Filed survey } \\
\mathrm{N}=274\end{array}$ & Individual & $\begin{array}{l}\text { Webhelp } \\
\text { Centralization } \\
\text { Records } \\
\text { Goal ambiguity } \\
\text { Internal communication } \\
\text { Bureaucratic culture } \\
\text { Innovation culture } \\
\text { Red tape } \\
\text { External communication } \\
\text { Political influence } \\
\text { Customer orientation } \\
\text { Budget } \\
\text { Program } \\
\text { Client groups pressure } \\
\text { State pressure } \\
\text { National political influence } \\
\text { Regulatory pressure. }\end{array}$ & $\begin{array}{l}\text { Website effectiveness was positively } \\
\text { related to } \\
\text { external political and business pressures, } \\
\text { internal } \\
\text { communication characteristics, innovative } \\
\text { organizational culture, and size. } \\
\text { External pressures positively affected } \\
\text { Website } \\
\text { adoption by legitimating internal } \\
\text { managerial } \\
\text { actions. } \\
\text { Website adoption is effective when } \\
\text { organizations } \\
\text { are entrepreneurial, innovative, and open } \\
\text { to } \\
\text { external influence. }\end{array}$ \\
\hline $\begin{array}{l}\text { Gupta and } \\
\text { Jana } \\
\text { (2003) }\end{array}$ & $\begin{array}{l}\text { Case study } \\
N=1\end{array}$ & Project & $\begin{array}{l}\text { Cost benefit analysis } \\
\text { Benchmarking } \\
\text { Scoring method } \\
\text { Stages of e-government } \\
\text { Sociological angle } \\
\end{array}$ & $\begin{array}{l}\text { Proposes a framework to measure e- } \\
\text { government tangible } \\
\text { and intangible benefits by combining hard } \\
\text { and soft } \\
\text { performance measures. }\end{array}$ \\
\hline
\end{tabular}




\section{Table 20: E-government adoption and acceptance: make work easier (adapted}

from: Titah and Barki, 2005)

\begin{tabular}{|c|c|c|c|c|}
\hline Authors & Methiniology & $\begin{array}{l}\text { Ievel of } \\
\text { andivis }\end{array}$ & $\begin{array}{l}\text { Wriables or lay } \\
\text { concents }\end{array}$ & Main results or arguments \\
\hline $\begin{array}{l}\text { Warkentin ef } \\
\text { al. } \\
(2002)\end{array}$ & $\begin{array}{l}\text { Technology } \\
\text { acceptance model } \\
\text { Theory of } \\
\text { planned } \\
\text { behavior } \\
\text { Trust literature }\end{array}$ & Individual & $\begin{array}{l}\text { Institutional structures } \\
\text { Disposition to trust } \\
\text { Characteristics-based } \\
\text { trust } \\
\text { Experience } \\
\text { PEOU } \\
\text { PU } \\
\text { Perceived behavioral } \\
\text { control } \\
\text { Perceived risk } \\
\text { Degree of intrusiveness } \\
\text { Culture (uncertainty } \\
\text { avoidance) } \\
\text { Culture (power distance } \\
\text { acceptance) } \\
\text { Intention to engage in } \\
\text { egovernment }\end{array}$ & $\begin{array}{l}\text { Proposes a conceptual model of key } \\
\text { factors affecting } \\
\text { individual e-government adoption. }\end{array}$ \\
\hline $\begin{array}{l}\text { Robey and } \\
\text { Sahay } \\
\text { (1996) }\end{array}$ & $\begin{array}{l}\text { Case study } \\
\mathrm{N}=2\end{array}$ & Organizational & $\begin{array}{l}\text { Social consequences of } \\
\text { IT Organizational } \\
\text { transformation } \\
\text { Organizational learning }\end{array}$ & $\begin{array}{l}\text { The same IT was found to be } \\
\text { experienced differently in two } \\
\text { similar settings (counties). } \\
\text { IT consequences are "socially } \\
\text { constructed" and "depend } \\
\text { upon its social meanings more than its } \\
\text { material properties" } \\
\text { (p. 106). } \\
\text { The differences in consequences were } \\
\text { found to be related to } \\
\text { the differences in the implementation. }\end{array}$ \\
\hline
\end{tabular}

